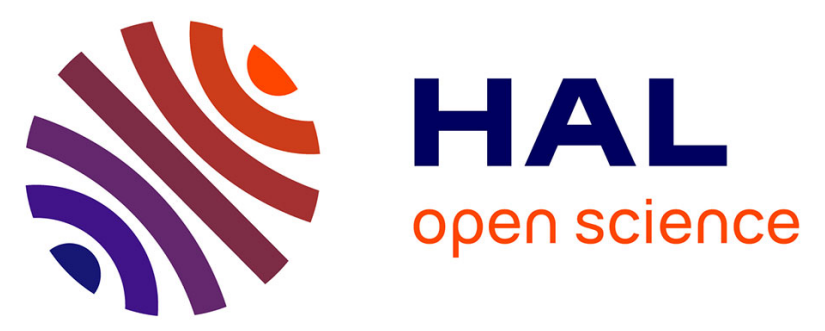

\title{
Fine particles at a background site in Central France: Chemical compositions, seasonal variations and pollution events
}

Lin He, Hui Chen, Jérôme Rangognio, Abderrazak Yahyaoui, Patrice Colin, Jinhe Wang, Véronique Daële, Abdelwahid S Mellouki

\section{To cite this version:}

Lin He, Hui Chen, Jérôme Rangognio, Abderrazak Yahyaoui, Patrice Colin, et al.. Fine particles at a background site in Central France: Chemical compositions, seasonal variations and pollution events. Science of the Total Environment, 2018, 612, pp.1159-1170. 10.1016/j.scitotenv.2017.08.273 . insu-01588962

\section{HAL Id: insu-01588962 \\ https://hal-insu.archives-ouvertes.fr/insu-01588962}

Submitted on 19 Oct 2017

HAL is a multi-disciplinary open access archive for the deposit and dissemination of scientific research documents, whether they are published or not. The documents may come from teaching and research institutions in France or abroad, or from public or private research centers.
L'archive ouverte pluridisciplinaire HAL, est destinée au dépôt et à la diffusion de documents scientifiques de niveau recherche, publiés ou non, émanant des établissements d'enseignement et de recherche français ou étrangers, des laboratoires publics ou privés. 


\title{
Fine particles at a background site in Central France: Chemical compositions, seasonal variations and pollution events
}

\author{
Lin $\mathrm{HE}^{1,2}$, Hui CHEN ${ }^{1}$, Jérôme RANGOGNIO ${ }^{3}$, Abderrazak YAHYAOUI ${ }^{3}$, Patrice \\ $\mathrm{COLIN}^{3}$, Jinhe WANG ${ }^{4}$, Véronique DAËLE ${ }^{1}$, Abdelwahid MELLOUKI $^{1,2, *}$ \\ 1 Institut de Combustion, Aérothermique, Réactivité et Environnement, CNRS, Orléans, France \\ 2 School of Environmental Science and Engineering, Shandong University, Jinan, People's Republic of China \\ 3 Lig'Air, Réseau de Surveillance de la Qualité de l'Air en Région Centre-Val de Loire, Saint-Cyr-en-Val, France \\ 4 School of Municipal and Environmental Engineering, Shandong Jianzhu University, Jinan 250101, and \\ Shanghai Key Laboratory of Atmospheric Particle Pollution and Prevention (LAP3), Department of \\ Environmental Science \& Engineering, Fudan University, Shanghai 200433, People’s Republic of China
}

\begin{abstract}
To expand our knowledge of regional fine particles in Central France (Centre-Val de Loire region), a field observation study of PM2.5 was carried out at Verneuil site (46.81467N, 2.61012E, 180 m.a.s.1.) from 2011 to 2014. The mass concentrations of water-soluble inorganic ions (WSIIs), organic carbon (OC), elemental carbon (EC) and biomass burning tracer (Levoglucosan) in PM2.5 were measured. Annual average PM2.5 mass concentrations were 11.8, 9.5, 12.6 and $10.2 \mu \mathrm{g} \mathrm{m}^{-3}$ in 2011, 2012, 2013 and 2014, respectively, three of four higher than the WHO guideline of 10 $\mu \mathrm{g} \mathrm{m}^{-3}$. Secondary inorganic aerosol (SIA) and organic matter (OM) appeared to be the major components in $\mathrm{PM}_{2.5}$ in Verneuil, contributing 30.1 - 41.8\% and 36.9 - 46.3\%, respectively. Main chemical species were observed in the following order: winter $\geq$ spring > autumn > summer. Backward atmospheric trajectories were performed using Hysplit model and suggested that the $\mathrm{PM}_{2.5}$ pollutants caused by atmospheric transport were mainly originated from European inland, mainly east to north-east areas. During the observation period, five pollution events were reported and indicated that not only the polluted air masses from central Europe but also the biomass burning from East Europe significantly influenced the air quality in Verneuil site.
\end{abstract}

Keyword: $\mathrm{PM}_{2.5}$, Chemical characteristics, Backward trajectory, Pollution events, Biomass burning, Central France 
*Corresponding author. E-mail: mellouki@cnrs-orleans.fr 


\section{Introduction}

Airborne particles have attracted intense scientific and public attention in recent years for their adverse effect on human health, visibility and climate (Koçak et al. 2007, Pateraki et al. 2014). In particular, fine particles (PM2.5, particulate matter with aerodynamic diameter $(\mathrm{AD})<2.5 \mu \mathrm{m}$ ) can remain in suspension much longer than coarse particles and can penetrate more deeply into the respiratory tract causing many kinds of reactions (oxidative stress, local pulmonary, systemic inflammatory responses, etc.) (Amodio et al. 2010, Maté et al. 2010). Furthermore, they have a clear impact on climate, causing direct (absorbing or reflecting the radiation, modifying the scattering), semi-direct (heating may cause the burn-off of clouds) and indirect (favoring or preventing the formation of clouds, their albedo and life-times) effects on the global radiative budget (Barker et al. 2007). Additionally, other effects are evident on visibility, building materials and ecosystems (Razak et al. 2015).

$\mathrm{PM}_{2.5}$ is a mixture of many species, loading complex information of air pollution. It consists mainly of water-soluble inorganic ions (WSIIs), carbonaceous species, crustal elements and trace elements. WSIIs, dominated by secondary ionic aerosols (SIA, including $\mathrm{NO}_{3}{ }^{-}, \mathrm{SO}_{4}{ }^{2+}$ and $\mathrm{NH}_{4}{ }^{+}$), are directly related to their precursor gases $\mathrm{SO}_{2}$, $\mathrm{NO}_{x}$ and $\mathrm{NH}_{3}$, with rather well known sources mostly related to fossil fuel burning $\left(\mathrm{SO}_{2}\right.$, $\left.\mathrm{NO}_{x}\right)$ and agriculture $\left(\mathrm{NH}_{3}\right)$, and can directly affect the acidity of precipitation as well as atmospheric visibility (Pathak et al. 2011, Zhang et al. 2015). Organic carbon (OC), which comprises thousands of organic compounds, originates from both natural and 
anthropogenic sources and contains many toxic substances, such as polycyclic aromatic hydrocarbons (PAHs) and normal alkanes ( $\mathrm{Li}$ et al. 2013). Element carbon (EC), existing in an inert state, is directly emitted from primary combustion and plays an important role on radiative forcing and climate system (Srinivas and Sarin 2014). The crustal elements ( $\mathrm{Mg}, \mathrm{Al}, \mathrm{K}, \mathrm{Ca}$ and $\mathrm{Fe})$, mainly from soil or construction dust, are also important factors leading to degradation of visibility (Tian et al. 2016). The annual, seasonal and daily tendencies of these chemical compositions have been widely used to identify the sources responsible for the PM pollution in the atmosphere.

Europe, as the most developed continent, has experienced serious air pollution in the history and keeps launching thematic strategy on air pollution since then. The most recent wave of policy was launched in 2005 including control on PM. In order to understand the impact of human activities on the atmospheric environment and assess air pollution over a regional area, it is important to monitor air quality in the regional/background area in addition to that in the urban/polluted area.

In Europe, studies on fine particles at background sites in recent years have been reported for a number of areas such as Veneto (Italy), Diabla Góra (Poland), Montseny (Spain), Melpitz (Germany) (Bressi et al. 2012, Khan et al. 2016, Pey et al. 2009, Rogula-Kozłowska et al. 2014). These sites were far away from cities and industrial areas and $\mathrm{PM}_{2.5}$ mass concentrations at these background sites showed similar seasonal variation trends, lower in the summer and higher in the winter and spring. Based on the chemical composition and trajectory analysis, natural sources were considered as the main contributor to fine particles in the summer, while mid- or long-range transport 
anthropogenic sources such as fossil fuel combustion and biomass burning contributed more in the winter and spring. Additionally, oceanic wind played a clean-up role for those coastal sites near the Atlantic.

In France, studies were mainly found at urban and suburban measurement sites around large cities (Cazier et al. 2016, Dimitriou and Kassomenos, El Haddad et al. 2011, Fortems-Cheiney et al. 2016, Kfoury et al. 2016). Particle pollution in these areas were regarded as a complex consequence of industrial, domestic and traffic (shipping for dock cities) emissions. As we were aware of, there is only study in Rubrouck, North France, where $\mathrm{PM}_{2.5}$ were mainly from natural emissions in the summer and $\mathrm{PM}_{2.5}$ concentration peaks recorded in spring with high SIA contributions was highly related to the accumulation phenomena and long-range transport from the Eastern and Central Europe origins (Cazier et al. 2016).

In a recent study on the origin of PM pollution in Paris, Beekmann et al. (2015) have reported that primary fossil fuel combustion emissions constituted less than $20 \%$ in winter and $40 \%$ in summer of carbonaceous fine PM, suggesting that the major part of secondary organic aerosol (SOA) is of modern origin, i.e., from biogenic precursors and from wood burning.

In our earlier study in Orléans site, by monitoring particle size distribution and aerosol extinction coefficients at a suburban measurement site in central France, it was pointed out that Atlantic Ocean air masses could clean up regional pollution in the winter. Meanwhile, this region can be influenced by air masses originating from other European areas, Atlantic Ocean, Mediterranean Sea air masses and African dust plume 
but their corresponding impacts in different seasons are not yet clear (Hu et al. 2014).

To expand our knowledge of regional fine particles in Central France, a field observation study of $\mathrm{PM}_{2.5}$ was carried out at Verneuil site from 2011 to 2014 . Herein, temporal concentration variations of $\mathrm{PM}_{2.5}$ and their chemical compositions were reported; interrelations between different compositions were studied; primary and secondary organic sources of $\mathrm{PM}_{2.5}$ were evaluated; backward trajectories were analyzed to identify the influence of mid- or long-range atmospheric transport; and several pollution events were reported.

\section{Material and methods}

\subsection{Measurement site}

Verneuil (46.81467N, 2.61012E, 180 m.a.s.1.) is a rural background site located in the center of France, in the southeast of the Centre-Val de Loire region and $230 \mathrm{~km}$ south to Paris. As illustrated in Fig. s1, the surrounding areas of Verneuil site are mainly grassland and forest, with two two-lane roads and a few residence houses nearby. The samplers and the inlets of instruments were placed on the roof, $3.5 \mathrm{~m}$ above the ground. Verneuil is part of MERA observatory within the framework of EMEP project (http://ce.mines-douai.fr/pages/observatoire-mera or http://www.emep.int/).

\subsection{Fine aerosol particles measurement}

$\mathrm{PM}_{2.5}$ were measured by Lig'Air, the Centre-Val de Loire Region Air Quality Observatory, continuously during 2011 to 2014 by TEOM-FDMS (Thermal, TEOM 
1400 with an FDMS 8500 module, TEOM: Tapered Element Oscillating Microbalance, FDMS: Filter Dynamics Measurement System). It was operated at a standard flow-rate of $1 \mathrm{~L} \cdot \mathrm{min}^{-1}$ with a $2.5 \mu \mathrm{m}$ cutting head. The mass loss due to volatilization is corrected by FMDS module. PM10 were measured simultaneously during 2010 to 2011 using the same system but with a $10 \mu \mathrm{m}$ cutting head and at a standard flow-rate of $1 \mathrm{~L} \cdot \mathrm{min}^{-1}$. The filter was replaced when its loading percentage was greater than $30 \%$ to keep the flow rate. Further details of TEOM-FDMS can be found elsewhere (Patashnick and Rupprecht 1991). The PM concentrations used in this paper are hourly averages from 5-min measurements by TEOM-FDMS.

\subsection{Chemical analyses}

\subsubsection{Aerosol sampling}

Fine aerosol particles $\left(\mathrm{PM}_{2.5}\right)$ were collected by Lig'Air for 24 hours (9:00 am to 9:00 am UT) every 7 days using a DIGITEL DA-80 high volume sampler. All the samples were collected on $47 \mathrm{~mm}$ quartz filters (Whatman Inc., Maidstone, UK). All quartz filters were pre-baked at $450{ }^{\circ} \mathrm{C}$ for $4 \mathrm{~h}$ and without binding to have very low levels of blank. After collection, samples were sent to laboratory (Laboratoire des Sciences du Climat et de l'Environnement (LSCE) et Laboratoire de Glaciologie et Géophysique de l'Environnement (LGGE)) for chemical analyses within 4 hours. A total of 224 filters have been collected and few samples have been discarded because of power failures, chemical analysis problems, etc.

\subsubsection{Water Soluble Ions}


The following water-soluble major ions were analyzed by Ion Chromatographs (IC) (model Dionex ICS 3000): chloride, nitrate, sulfate, sodium, ammonium, potassium, magnesium and calcium. The analytical protocol conformed to the Lig'Air technical report TR-16269 CEN / TC 264. Briefly, filter samples were extracted in 15 $\mathrm{mL}$ of ultrapure water during $45 \mathrm{~min}$ in a sonic bath. To prevent bacteria activity, $50 \mu \mathrm{L}$ of chloroform was added in the extractions. Samples were then filtered using Acrodisc filters (Pall Gelman) with a porosity of $0.22 \mu \mathrm{m}$. CS16 column was used for cation analyses while AS11 HC column for anion. Calibration was performed daily from certified standard solutions. The detection limits were less than $0.05 \mu \mathrm{g} \mathrm{m}^{-3}$ for each ion.

\subsubsection{Carbonaceous contents}

The carbonaceous content of samples was analyzed for EC and OC using a Thermo-Optical Transmission (TOT) method on a Sunset Lab analyzer (Birch 1998). Recently developed EUSAAR2 temperature program was used here (Cavalli et al. 2010). Briefly, it includes temperature from 200 to $650{ }^{\circ} \mathrm{C}$ for the analysis of OC in $100 \% \mathrm{He}$, and from 500 to $850{ }^{\circ} \mathrm{C}$ for the analysis of $\mathrm{EC}$ in $98 \% \mathrm{He}+2 \% \mathrm{O}_{2}$. A detailed description concerning thermal optical methods and the relevance of the

protocol chosen can be found elsewhere (Cavalli et al. 2010, Chow et al. 1993). Calibrations were performed daily. The detection limit and the uncertainty are estimated to be $0.2 \mu \mathrm{g}$ and $5 \%$, respectively.

\subsubsection{Monosaccharides anhydrides (MA) and polyols}

For the analysis of MA (Levoglucosan, mannosan and galactosan) and polyols 
(arabitol, sorbitol and mannitol), filter punches $\left(4.5 \mathrm{~cm}^{2}\right.$ ) were extracted with $2 \mathrm{~mL}$ ultrapure water by 30 min vortex agitation. Filter extracts were analyzed by HPLC (high-performance liquid chromatography) with a PAD (pulsed amperometric detection) detector (model Dionex DX500 + ED400). Column used were Metrosep Carb 1 - 6 Guard, A Supp $15-150$ and Carb 1 - 150. Eluent was 6.0 mol L ${ }^{-1} \mathrm{NaOH}$ and flow rate was $1 \mathrm{~mL} \mathrm{~min}^{-1}$. External calibrations were performed using standard solutions.

\subsection{Chemical mass closure}

Aerosol Chemical Mass Closure (CMC) consists in comparing the sum of the major aerosol chemical species $\left(\mathrm{PM}_{2.5-\mathrm{chem}}\right)$ with measurements $\left(\mathrm{PM}_{2.5 \text {-meas }}\right)$. When achieved (i.e. when $\mathrm{PM}_{2.5 \text {-chem }}=\mathrm{PM}_{2.5 \text {-meas }}$ ), $\mathrm{CMC}$ attests the consistency of chemical analyses, and confirms that all the major aerosol chemical species are quantified. PM2.5chem calculation is here expressed as:

$\left[\mathrm{PM}_{2.5-\mathrm{chem}}\right]=[$ Sea Salt $]+[$ Dust $]+[$ Secondary Inorganic Aerosols $]+$ [Carbonaceous Matter]

[Sea salt] (ss-) concentrations are calculated from the six major ions accounting for more than $99 \%$ of the mass of salts dissolved in seawater:

$[$ Sea salt $]=\left[\mathrm{Na}^{+}\right]+\left[\mathrm{Cl}^{-}\right]+\left[\mathrm{Mg}^{2+}\right]+\left[\mathrm{ss}-\mathrm{K}^{+}\right]+\left[\mathrm{ss}^{-} \mathrm{Ca}^{2+}\right]+\left[\mathrm{ss}-\mathrm{SO}_{4}{ }^{2-}\right]$

With $\left[\mathrm{ss}-\mathrm{K}^{+}\right]=0.036 \cdot\left[\mathrm{Na}^{+}\right] ;\left[\mathrm{ss}-\mathrm{Ca}^{2+}\right]=0.038 \cdot\left[\mathrm{Na}^{+}\right]$and $\left[\mathrm{ss}-\mathrm{SO}_{4}{ }^{2-}\right]=0.252 \cdot\left[\mathrm{Na}^{+}\right]$

Typical seawater ion ratios based on the average seawater composition are taken from Seinfeld and Pandis (Seinfeld et al. 2006).

[Dust]: The mineral dust fraction in $\mathrm{PM}_{2.5}$ can be quantified by different methods, 
which are based on its average elemental composition from specific sites, or on specific tracers (Guieu et al. 2002, Sisler and Huffman 1994). More recently, nss-calcium ("nss-" standing for non-sea-salt) has been widely used because of its abundance (Jean-P. et al. 2003, Sciare et al. 2005). Here in this paper, $15 \%$ contribution of nss-calcium in mineral dust determined by Guinot et al. was used (Guinot et al. 2007).

$$
[\text { Dust }]=\left[\mathrm{nss}^{-} \mathrm{Ca}^{2+}\right] / 0.15
$$

The resulting proportion of dust in $\mathrm{PM}_{2.5}$ during the whole campaign ranges from 1.1 to $5.2 \%$ on average from 2011 to 2014 (Fig. 4), which was in agreement with that in Paris (2\% to $5 \%$ ) (Bressi et al. 2012).

[Secondary inorganic aerosols] (SIA) are calculated as:

$$
[\mathrm{SIA}]=\left[\mathrm{nss}^{-} \mathrm{SO}_{4}{ }^{2-}\right]+\left[\mathrm{NO}_{3}{ }^{-}\right]+\left[\mathrm{NH}_{4}{ }^{+}\right]
$$

where $\left[\mathrm{nss}^{-} \mathrm{SO}_{4}{ }^{2-}\right]=\left[\mathrm{SO}_{4}{ }^{2-}\right]-\left[\mathrm{ss}_{-} \mathrm{SO}_{4}{ }^{2-}\right]$.

[Carbonaceous matter] can be expressed as:

$[$ Carbonaceous Matter $]=[\mathrm{EC}]+[\mathrm{OM}]$

$[\mathbf{O M}]$ is inferred from $\mathrm{OC}$ as:

$$
[\mathrm{OM}]=\mathrm{fOC}^{-\mathrm{OM}} \cdot[\mathrm{OC}]
$$

fOC-OM is the $\mathrm{OC}$ to $\mathrm{OM}$ conversion factor.

OC was measured by the Sunset Lab analyzer conveniently, while OM include C, $\mathrm{O}, \mathrm{N}, \mathrm{H}$ etc., which is difficult to be quantified. The varied chemical composition, highly dependent on locations, seasons and time of the day, makes the estimation of OM complex. Turpin and Lim (2001) then recommend the measurement of the average molecular weight per carbon weight in the location of interest, corresponding to a foc- 
om of $1.6 \pm 0.2$ and $2.1 \pm 0.2$ for urban and nonurban aerosols, respectively. To estimate the foC-OM from our own dataset, a method adapted from Guinot et al. (2007) who used the chemical mass closure technique as a tool to assess foc-OM from OC measurements was applied.

In this method, $\mathrm{CMC}$ was assumed to be achieved $\left(\mathrm{PM}_{2.5 \text {-chem }}=\mathrm{PM}_{2.5 \text {-meas }}\right)$ and following equation could be got from equation (1):

$$
\text { foC-OM }=1 /[\mathrm{OC}] \cdot\left(\left[\mathrm{PM}_{2.5-\mathrm{meas}}\right]-([\text { Sea Salt }]+[\mathrm{Dust}]+[\mathrm{SIA}]+[\mathrm{EC}])\right)
$$

to simplify equation (7), [Remaining Mass] was defined as:

$$
[\text { Remaining Mass }]=\left[\mathrm{PM}_{2.5 \text {-meas }}\right]-([\text { Sea Salt }]+[\text { Dust }]+[\text { SIA }]+[\text { EC }])
$$

and lead to:

$$
[\text { Remaining Mass }]=\text { foC }-\mathrm{OM} \cdot[\mathrm{OC}]
$$

thus, foC-OM could be calculated as the slope of the linear regression from the plot of [Remaining Mass] against [OC]. Excluded days with foc-OM higher than 4 and lower than 1 which were considered as physically meaningless, foc-OM was calculated as 2.066. Finally, in order to make an easy comparison with whole chemical component data from Paris, foc-OM was chose as 2.05 (Bressi et al. 2012).

2.5 Meteorological parameters and backward trajectories

Meteorological parameters such as temperature, pressure, precipitation, wind speed and wind direction were obtained from http://www.wunderground.com/, which shares reliable and meaningful weather information with the public since 1993 by the weather company in San Francisco. Air mass backward trajectories were calculated using the 
Hybrid Single Particle Lagrangian Integrated Trajectory (HYSPLIT) model (Stein et al. 2015) and fire spots data were obtained from NASA FIRMS (http://earthdata.nasa.gov/data/near-real-time-data/firms).

\section{Result and discussion}

\section{1 $\mathrm{PM}_{2.5}$ levels}

The profiles of $\mathrm{PM}_{2.5}$ and $\mathrm{PM}_{10}$ mass concentrations in daily average from 2011 to 2014 at Verneuil site are given in Fig. 1. The annual average PM 2.5 mass concentrations from 2011 to 2014 were $11.8,9.5,12.6$ and $10.2 \mu \mathrm{g} \cdot \mathrm{m}^{-3}$, respectively. These annual averages, three of four, were higher than World Health Organization guideline of 10 $\mu \mathrm{g} \cdot \mathrm{m}^{-3}$ (WHO 2006). Compared with other rural background sites in Europe (Table 1), Verneuil site appeared to be less polluted by $\mathrm{PM}_{2.5}$ pollutions. The differences in $\mathrm{PM}_{2.5}$ level between those sites can probably be ascribed to the local energy structures, site locations and meteorological conditions. France and Switzerland possess larger clean energy shares such as nuclear power and hydroelectricity, leading to the relative low pollution emissions compared with the other countries of more fossil fuel consumption (OECD. 2014).

PM2.5 mass concentrations showed similar seasonal pattern from 2011 to 2014 with high levels in spring (Mar, Apr and May) and winter (Dec, Jan and Feb) and low levels in summer (Jun, Jul and Aug) and autumn (Sep, Oct and Nov), except in the winter of 2014 (low $\mathrm{PM}_{2.5}$ level might be partly explained by the absence of high 
pollution events in this season). The daily average mass concentrations of $\mathrm{PM}_{2.5}$ ranged from 1.3 to $78.8 \mu \mathrm{g} \cdot \mathrm{m}^{-3}$. High-pollution events, identified by daily average of $\mathrm{PM}_{2.5}$ larger than $50 \mu \mathrm{g} \cdot \mathrm{m}^{-3}$, have occurred every year during February or March, as listed in Table 3, and would be further discussed in detail in section 3.4. Box plots of hourly $\mathrm{PM}_{2.5}$ mass concentration distributions for the whole measurement period was given in Fig. s2. No evident variation of $\mathrm{PM}_{2.5}$ was found during rush hours which indicated that Verneuil was barely influenced by vehicle emission on the roadside.

As illustrated in Fig. 1, PM10 mass concentrations during 2011 and 2012 showed the same variation trend as $\mathrm{PM}_{2.5}$. The $\mathrm{PM}_{2.5} / \mathrm{PM}_{10}$ ratios varied in a range of $0.28-1$ with an average of 0.74 . This result was also consistent with those from other European regions (annual $\mathrm{PM}_{2.5} / \mathrm{PM}_{10}$ ratio of 0.79 in Germany, 0.86 in Spain and 0.72 in Switzerland) (Pey et al. 2009). Sample number distribution of $\mathrm{PM}_{2.5} / \mathrm{PM}_{10}$ ratios against $\mathrm{PM}_{2.5}$ mass concentrations is shown in Fig. s3. During the clean days $\left(\mathrm{PM}_{2.5}<10 \mu\right.$ $\mathrm{g} \cdot \mathrm{m}^{-3}$ ), samples mainly distributed in the areas of $\mathrm{PM}_{2.5} / \mathrm{PM}_{10}$ ratio below 0.7 , whereas during pollution days $\left(\mathrm{PM}_{2.5}>20 \mu \mathrm{g} \cdot \mathrm{m}^{-3}\right)$, the $\mathrm{PM}_{2.5} / \mathrm{PM}_{10}$ ratios were high $(0.8-1.0)$. Thus, it was considered that $\mathrm{PM}_{2.5}$ rather than $\mathrm{PM}_{10}$ were mainly responsible for $\mathrm{PM}$ pollution in Verneuil during 2011 and 2012. 


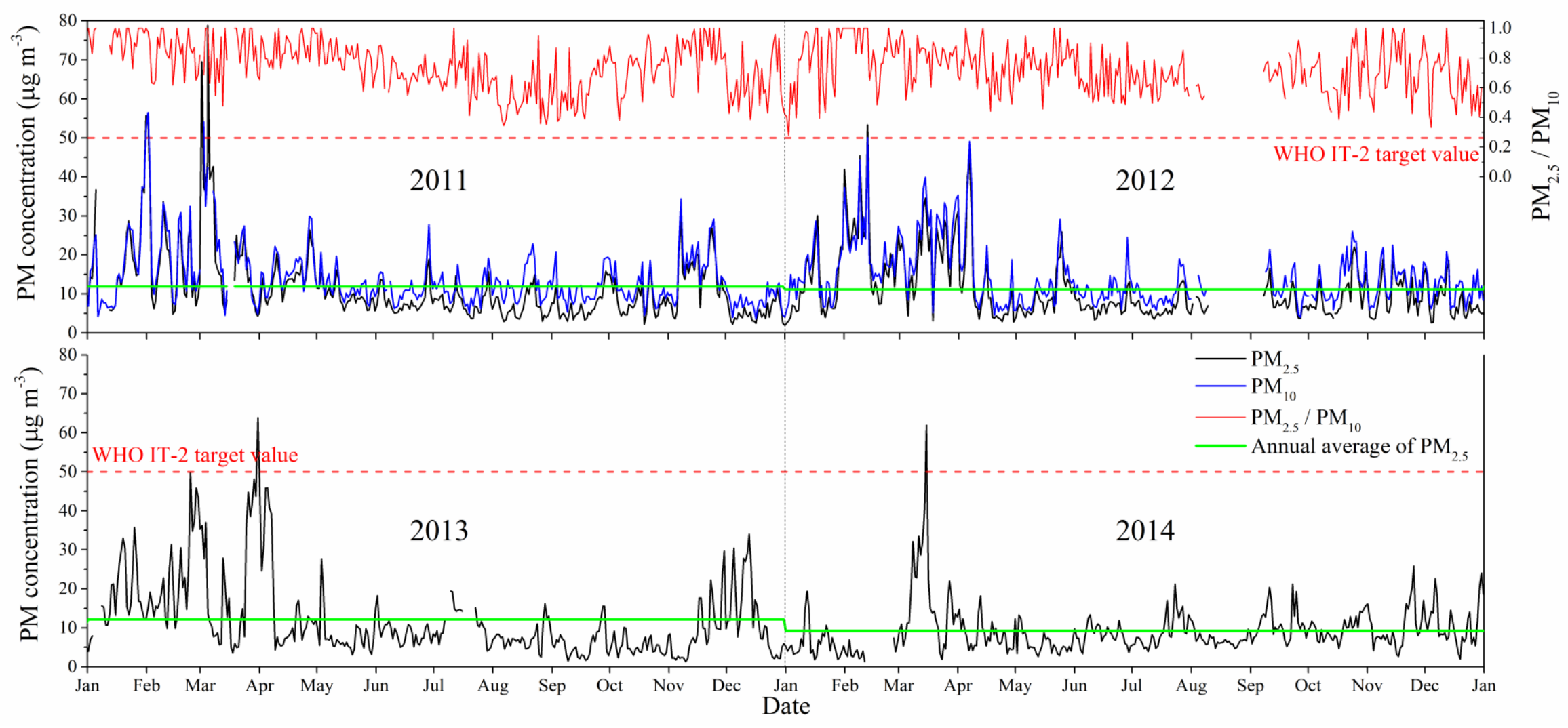

Fig. 1. Daily averages of $\mathrm{PM}_{2.5}$ and $\mathrm{PM}_{10}$ mass concentrations measured by TEOM-FDMS and ratio of $\mathrm{PM}_{2.5}$ to $\mathrm{PM}_{10}\left(\mathrm{PM}_{2.5} / \mathrm{PM}_{10}\right)$ from 2011 to 2014. Daily averages were calculated from 0:00 am to 0:00 am. 
3.2 Chemical composition

\subsubsection{General description}

Filter samples were collected for chemical composition analysis for 24 hours (from 9:00 am to 9:00 am UT) every 7 days. Fig. 2 shows the mass concentrations of $\mathrm{PM}_{2.5}$ and its corresponding main species. Different from "PM 2.5 " in Fig. 1, "PM2.5 Measured" were PM2.5 mass concentrations specially averaged from 9:00 am to 9:00 am in next day by TEOM-FDMS to get consistence with filter sample data of the other species. 


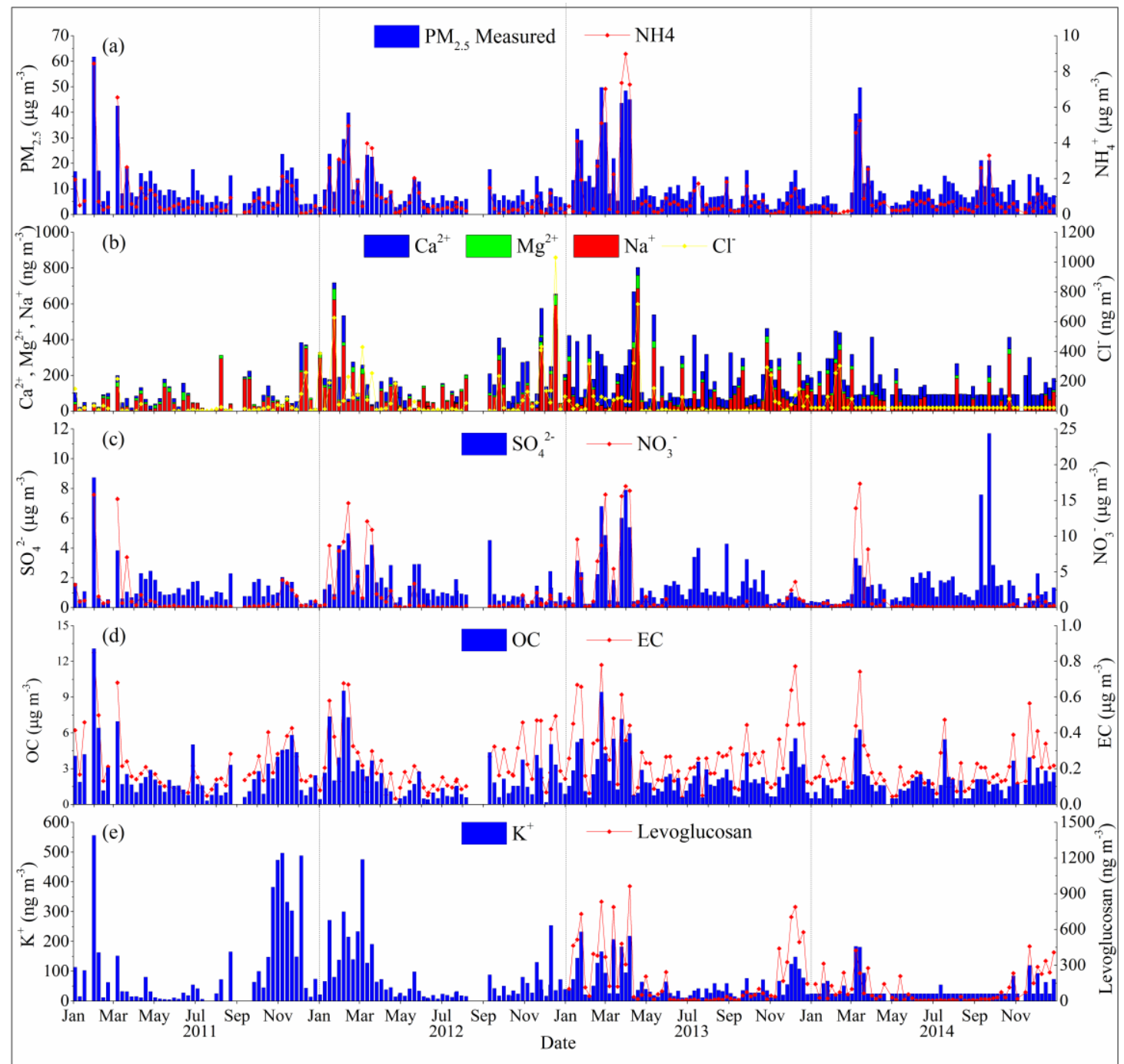

Fig. 2 Daily averages of PM 2.5 mass concentrations measured by TEOM-FDMS and the mass concentrations of main chemical compositions from 2011 to 2014 in Verneuil. Daily averages of $\mathrm{PM}_{2.5}$ measured were calculated from 9:00 am to 9:00 am. Note that different units have been used for the figures. 
$\mathrm{PM}_{2.5}$ Reconstructed was calculated from chemical species and shown in Fig. 3. The good consistency between PM2.5 Measured and PM2.5 Reconstructed confirmed the accuracy of our field measurements and verified the conversion factors (foc-om) used to estimate organic matter in this paper. The mass shares of the identified components in $\mathrm{PM}_{2.5}$ were lowest in summer and highest in winter, varied in the range of $54.4 \%$ $60.5 \%$ and $74.2 \%-99.6 \%$, respectively.

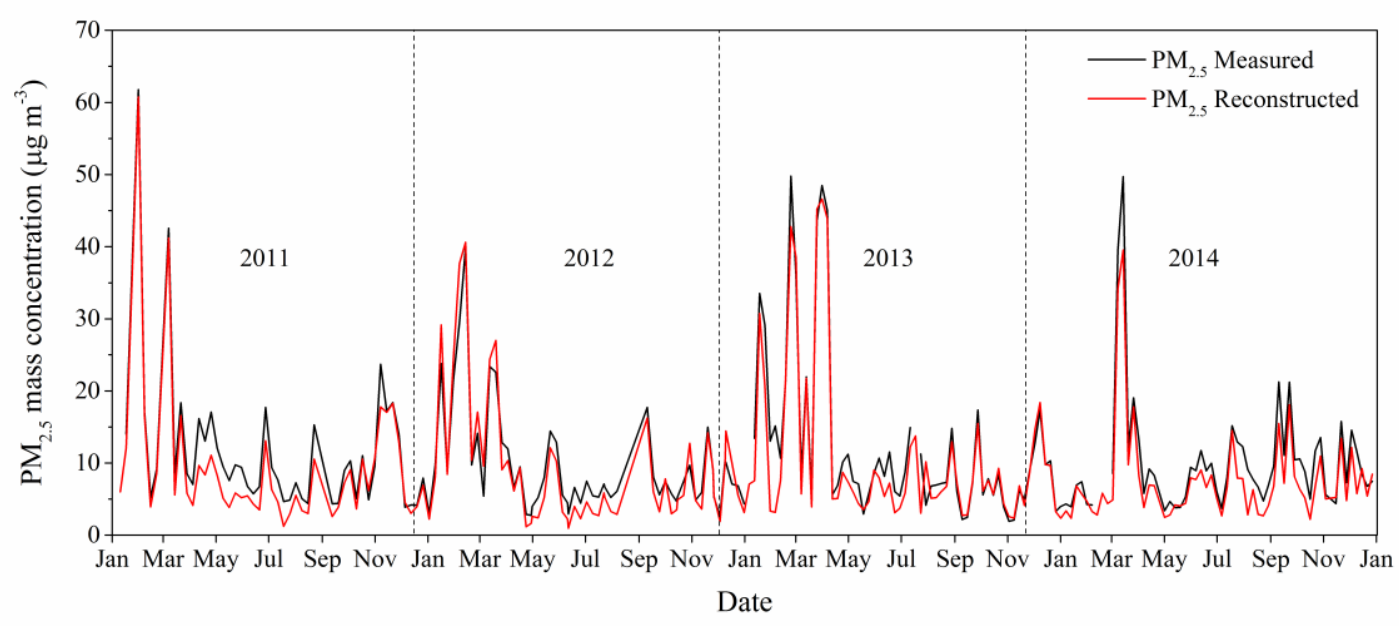

Fig. 3 Daily averages of PM2.5 mass concentrations measured by TEOM-FDMS and $\mathrm{PM}_{2.5}$ reconstructed from chemical mass closure by filter sampling from 2011 to 2014. Daily averages of $\mathrm{PM}_{2.5}$ Measured were calculated from 9:00 am to 9:00 am.

The difference between the $\mathrm{PM}_{2.5}$ Measured and $\mathrm{PM}_{2.5}$ Reconstructed was defined as unidentified matter (UM) including some trace elements, carbonaceous, and/or organic anions which were not covered by the analysis, or evaporated components such as water and ammonium nitrate during sampling, storage and transportation of samples (Rogula-Kozłowska et al. 2014).

The UM contributed more in the summer $(18.3 \%-32.9 \%$, Table s1) and less in the winter $(0 \%-22.0 \%)$. This can be probably explained by that (a) in hot and dry 
period, nitrates and some organic compounds might get lost by evaporation during storage and transportation of samples; (b) while in winter or spring, identified mass of $\mathrm{PM}$ can be overestimated due to the adsorption of $\mathrm{SO}_{2}$ onto ammonia-rich particles or adsorption of nitric acid ( $\left.\mathrm{HNO}_{3}\right)$ onto mineral and salt particles (Pathak et al. 2009).

Annual and seasonal averages of $\mathrm{PM}_{2.5}$ mass concentrations and corresponding chemical composition shares are shown in Fig. 4 (mass concentrations are given in Table s1). Among identified components, SIA and OM appeared to be the major components in $\mathrm{PM}_{2.5}$ in Verneuil, contributing 30.1 - 41.8\% and $36.9-46.3 \%$, respectively. SIA shares varied in the reported ranges of other European rural background sites, while OM shares were close to rural background sites near Paris (40\% to $47 \%$ ) and much higher than other European sites (21.0\% to 32.6\%) (Table 1) (Bressi et al. 2012, Khan et al. 2016, Pey et al. 2009, Pirovano et al. 2015, Putaud et al. 2010). OM was reported to be originated from biomass burning, SOA formation, mid- or longrange transport, and traffic emission (Bressi et al. 2012, Khan et al. 2016). High OM shares in Verneuil was largely attributed to biomass burning and/or SOA formation in winter/spring, while solely to SOA formation favored by biogenic volatile organic compounds (VOCs) emission and solar irradiation in summer/autumn (see discussion in section 3.2.3). SIA were originated from transport from Europe inland and gas-toparticle conversion by precursors $\left(\mathrm{SO}_{2} \mathrm{NO}_{x}, \mathrm{NH}_{3}\right)$ in excess of ammonia and under favorable thermodynamic conditions (Bressi et al. 2012, Clegg et al. 1998, Hamaoui 2012) (see discussion in section. 3.2.2). 


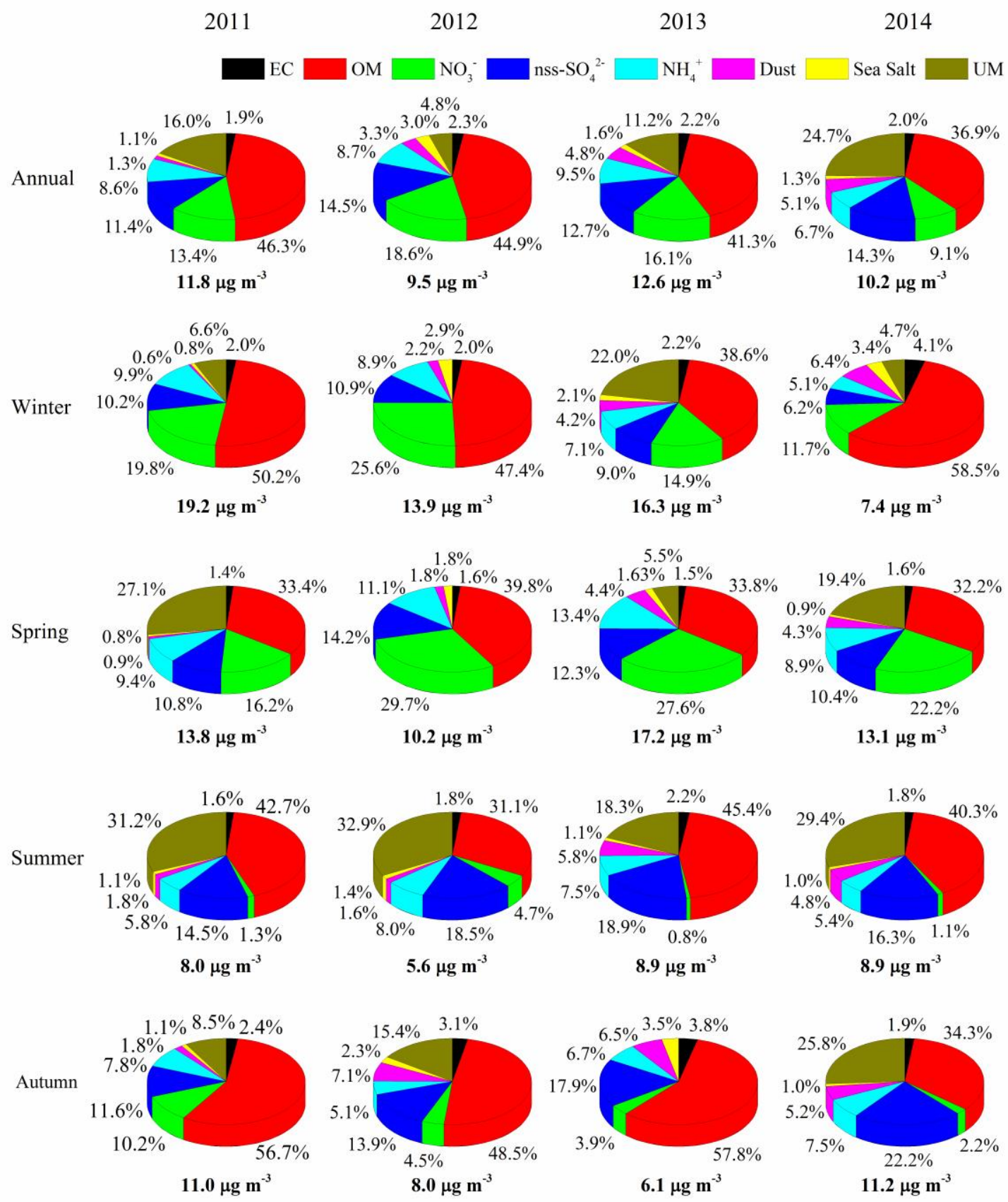

Fig. 4 Annual and seasonal average PM2.5 mass concentration measured by TEOMFDMS and corresponding chemical composition shares from 2011 to 2014. Daily averages of $\mathrm{PM}_{2.5}$ Measured were calculated from 9:00 am to 9:00 am. 
Table 1 Average mass concentration of $\mathrm{PM}_{2.5}$ and its main compositions at different rural site in Europe (OM: organic matter, SIA: secondary

\begin{tabular}{|c|c|c|c|c|c|c|}
\hline location (country) & Type & Measurement period & $\begin{array}{l}\mathrm{PM}_{2.5} \\
\left(\mu \mathrm{g} \mathrm{m}^{-3}\right)\end{array}$ & $\begin{array}{l}\mathrm{OM} \\
\%\end{array}$ & $\begin{array}{l}\text { SIA } \\
\%\end{array}$ & Data source \\
\hline Verneuil & Rural & 2011-2014 & $9.5-12.6$ & $36.9-46.3$ & $30.1-41.8$ & This study \\
\hline South Paris (France) & Rural & 09/2009-09/2010 & 10.8 & 40.0 & 48.0 & M. Bressi et al. 2012 \\
\hline Northeast Paris (France) & Rural & 09/2009-09/2010 & 12.6 & 47.0 & 42.0 & M. Bressi et al. 2012 \\
\hline Chaumont (Switzerland) & Rural & 1998 & 8.1 & 21.0 & 43.1 & J.-P. Putaud et al. 2010 \\
\hline Diabla Góra (Poland) & Rural & 2010 & 15.0 & 21.2 & 36.3 & W. Rogula-Kozlowska et al. 2014 \\
\hline Streithofen (Austria) & Rural & 1999-2000 & 17.5 & 25.7 & 35.4 & J.-P. Putaud et al. 2010 \\
\hline Hortobágy (Hungary) & Rural & 1995-1998 & 18.0 & - & - & J.-P. Putaud et al. 2010 \\
\hline Bosco Fontana (Italy) & Rural & 2004-2007 & 34.7 & - & - & G. Pirovano et al. 2015 \\
\hline Montseny (Spain) & Rural & 2003 & 13.6 & 27.0 & 36.0 & J. Pey et al. 2009 \\
\hline Paris (France) & Urban & 09/2009-09/2010 & 14.8 & 39.0 & 43.0 & M. Bressi et al. 2012 \\
\hline Königsplatz (German) & Kerbside & $11 / 2007-03 / 2008$ & 43.0 & - & - & R.M. Qadir et al. 2014 \\
\hline Katowice (Poland) & Urban & 2010 & 43.0 & 25.8 & 21.7 & W. Rogula-Kozlowska et al. 2014 \\
\hline Zuerich (Switzerland) & Urban & 1998 & 19.0 & 23.2 & 41.0 & J.-P. Putaud et al. 2010 \\
\hline Milano (Italy) & Urban & 2004-2007 & 31.5 & - & - & G. Pirovano et al. 2015 \\
\hline Venice (Italy) & Residence & $2012-2013$ & 25.3 & 32.6 & & Md. Badiuzzaman Khan et al. 2016 \\
\hline Barcelona (Spain) & Urban & 2003-2006 & 29.0 & 31.0 & 29.7 & N. Perez et al. 2008 \\
\hline
\end{tabular}


The validity of the water soluble inorganic ions could be ascertained through the balance of anions and cations (Chow et al. 1994). The anion and cation microequivalents for the $\mathrm{PM}_{2.5}$ samples were calculated as follows:

$$
\begin{aligned}
& \mathrm{A}(\text { anion microequivalents })=\mathrm{Cl}^{-} / 35.5+\mathrm{SO}_{4}{ }^{2-} / 45+\mathrm{NO}_{3}{ }^{-} / 62 \\
& \mathrm{C}(\text { cation microequivalents })=\mathrm{Na}^{+} / 23+\mathrm{NH}_{4}{ }^{+} / 18+\mathrm{K}^{+} / 39+\mathrm{Mg}^{2+} / 12+\mathrm{Ca}^{2+} / 20
\end{aligned}
$$

As illustrated in Fig. 5, the average ratio of the molar equivalents $\left(\mathrm{eq}^{-3}\right)$ of cations $\left(\mathrm{Na}^{+}, \mathrm{NH}_{4}{ }^{+}, \mathrm{K}^{+}, \mathrm{Mg}^{2+}\right.$ and $\left.\mathrm{Ca}^{2+}\right)$ to anions $\left(\mathrm{Cl}^{-}, \mathrm{NO}_{3}{ }^{-}\right.$and $\left.\mathrm{SO}_{4}{ }^{2-}\right)$ was close to unity, i.e. $1.01 \pm 0.01$ in Verneuil, suggesting that almost all the ions had been quantified in this study, although bicarbonate and carbonate were not measured in this work. The strong correlation $\left(\mathrm{R}^{2}=0.97\right)$ between the anion and cation equivalents indicated that the relationship between the measured cations and anions remained constant during neutralization. Most of the samples collected were positioned close to the $1: 1$ cation:anion $(\mathrm{C}: \mathrm{A})$ line, implying that they were generally neutral. 


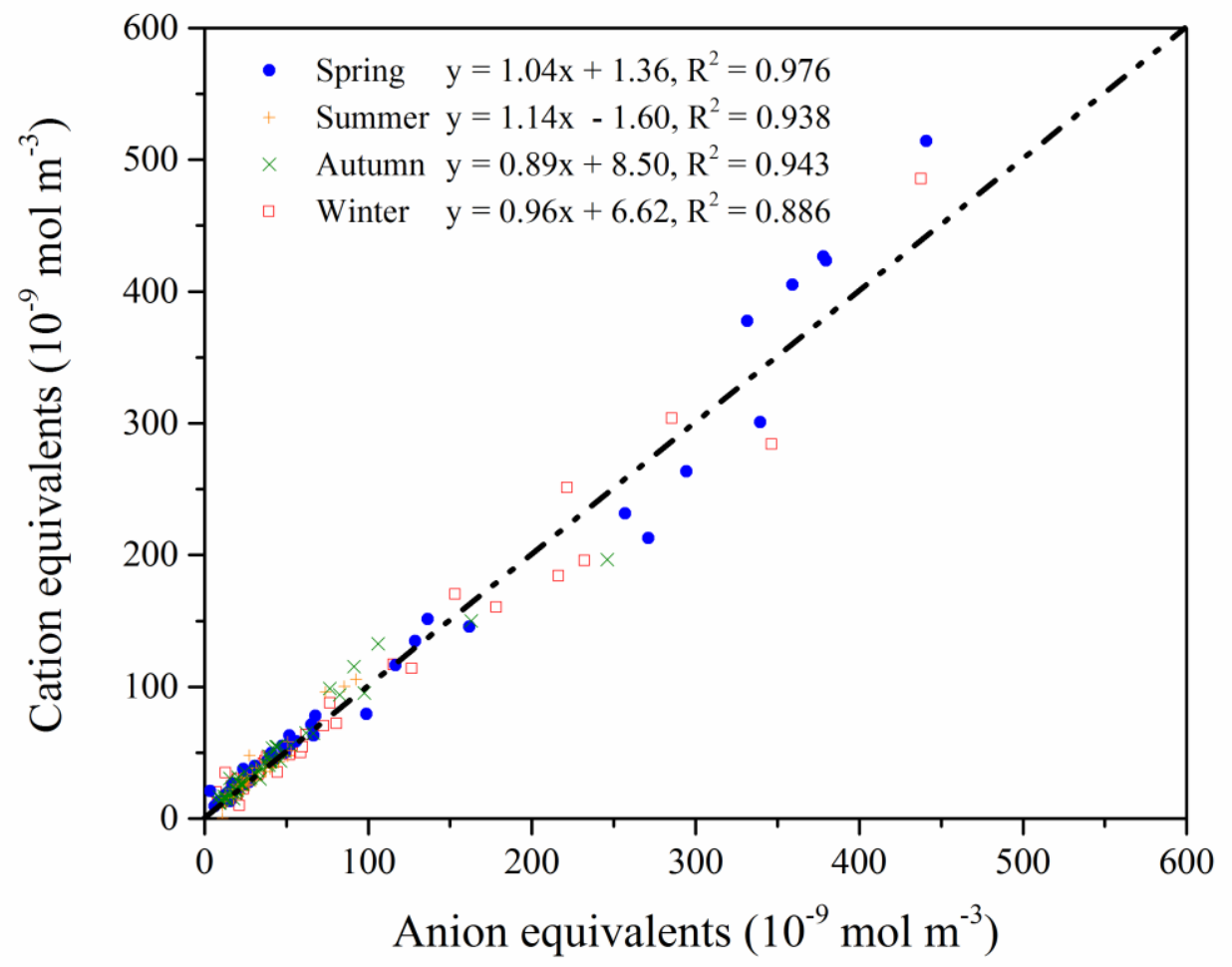

Fig. 5 The correlations between the anion and cation equivalents in the four seasons in Verneuil from 2011 to 2014. 1:1 dash line indicates the complete neutralization. Linear regressions for each season were calculated and equations were given. 
3.2.2 Secondary inorganic aerosol

SIA $\left(\mathrm{NO}_{3}{ }^{-}\right.$, nss- $\mathrm{SO}_{4}{ }^{2-}$ and $\left.\mathrm{NH}_{4}{ }^{+}\right)$shares showed clear seasonal tendencies in the order of spring $>$ winter $>>$ autumn $>$ summer (Fig. 4). High SIA contributions found in the spring/winter can be highly related to the higher emissions of SIA precursors $\left(\mathrm{NO}_{\mathrm{x}}\right.$ and $\left.\mathrm{SO}_{2}\right)$, accumulation phenomena and mid- or long-range transport. Seasonal average mass concentration of $\mathrm{NO}_{3}{ }^{-}, \mathrm{nss}_{-} \mathrm{SO}_{4}{ }^{2-}$ and $\mathrm{NH}_{4}{ }^{+}$are given in Table s1. Average of $\mathrm{NO}_{3}{ }^{-}$mass concentration was $3.24 \mu \mathrm{g} \cdot \mathrm{m}^{-3}$ in spring, which was 36 times higher than

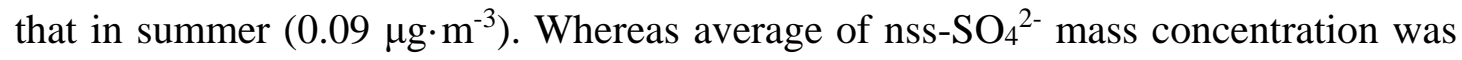
$1.68 \mu \mathrm{g} \cdot \mathrm{m}^{-3}$ in spring and $1.34 \mu \mathrm{g} \cdot \mathrm{m}^{-3}$ in summer. Although $\mathrm{NO}_{3}{ }^{-}$and $\mathrm{nss}_{-} \mathrm{SO}_{4}{ }^{2-}$ showed same seasonal variation trends with highest concentrations in spring/winter, the difference between the spring/winter and summer nss- $\mathrm{SO}_{4}{ }^{2-}$ concentrations was much smaller compared to that for $\mathrm{NO}_{3}{ }^{-}$. The low temperature favored the conversion of gaseous $\mathrm{HNO}_{3}$ to aerosol particles as $\mathrm{NH}_{4} \mathrm{NO}_{3}$, leading to higher contributions of SIA in spring and winter (Tao et al. 2012); and possibly, the formation of $\mathrm{SO}_{4}{ }^{2-}$ was enhanced by the increased photochemical reactivity in the summer (Choi et al. 2012).

The ratio of $\left[\mathrm{NH}_{4}{ }^{+}\right]$to $\left[\mathrm{SO}_{4}{ }^{2-}\right]$ is a common factor used to estimate the neutralization of all the three SIA species, which was defined as

$$
\left[\mathrm{NH}_{4}{ }^{+}\right] /\left[\mathrm{SO}_{4}{ }^{2-}\right]=\left(\mathrm{NH}_{4}{ }^{+} / 18\right) /\left(\mathrm{SO}_{4}{ }^{2-} / 96\right)
$$

Usually, area with $\left[\mathrm{NH}_{4}{ }^{+}\right] /\left[\mathrm{SO}_{4}{ }^{2-}\right]>1.5$ was regarded as ammonium-rich, and acidic sulfate is considered to be fully neutralized at $\left[\mathrm{NH}_{4}{ }^{+}\right] /\left[\mathrm{SO}_{4}{ }^{2-}\right] \geq 2$ (Huang et al. 2011). Annual averages of $\left[\mathrm{NH}_{4}{ }^{+}\right] /\left[\mathrm{SO}_{4}{ }^{2-}\right]$ were calculated from Table s1, which were 4.36, 
3.12, 3.94 and 2.49 in 2011 to 2014, respectively. All of them were significantly higher than 2. Meanwhile, $\mathrm{NO}_{3}{ }^{-}+\mathrm{SO}_{4}{ }^{2-}$ and $\mathrm{NH}_{4}{ }^{+}$microequivalents were calculated as follows,

$$
\mathrm{NO}_{3}{ }^{-}+\mathrm{SO}_{4}{ }^{2-} \text { microequivalents }=\mathrm{SO}_{4}{ }^{2-} / 48+\mathrm{NO}_{3}{ }^{-} / 62
$$

$\mathrm{NH}_{4}{ }^{+}$microequivalents $=\mathrm{NH}_{4}{ }^{+} / 18$

and their correlations in different seasons were plotted in Fig. s4. The slopes closed to the unity also indicated that most of $\mathrm{NO}_{3}{ }^{-}$and $\mathrm{SO}_{4}{ }^{2-}$ were neutralized with $\mathrm{NH}_{4}{ }^{+}$to form $\left(\mathrm{NH}_{4}\right)_{2} \mathrm{SO}_{4}$ and $\mathrm{NH}_{4} \mathrm{NO}_{3}$. To summarize, atmosphere in this area was regarded as ammonium saturated.

Bressi et al. (2012) reported ammonium-saturated SIA in Paris region with excess ammonia. In Verneuil, nitric acid can be easily converted to nitrate thanks to the great availability of ammonia probably originated from agricultural activity (Hamaoui 2012, Pey et al. 2009).

\subsubsection{Carbonaceous aerosols}

Carbonaceous aerosols, include organic carbon (OC, primarily or secondarily produced by gas-to-particle conversion from volatile organic compounds) and elemental carbon (EC, primarily from incomplete combustion). The annual averages of OC and EC mass concentrations in $\mathrm{PM}_{2.5}$ ranged from 1.83 to $2.67 \mu \mathrm{g} \cdot \mathrm{m}^{-3}$ and 0.20 to $0.28 \mu \mathrm{g} \cdot \mathrm{m}^{-3}$ in Verneuil site, respectively (Table $\mathrm{s} 1$ ). The low EC concentration indicated that there were no significant combustion emission sources nearby (Samara et al. 2013), in consistence with the absence of $\mathrm{PM}_{2.5}$ rush-hour peaks. The seasonally averaged OC and EC mass concentrations ranked in the descending order of winter > 
autumn $\approx$ spring $>$ summer as the $\mathrm{PM}_{2.5}$ mass concentrations. The relatively high levels of OC and EC in winter implying the aerosols were highly influenced by fossil fuel and/or wood burning for energy production and domestic heating.

\subsubsection{OC/EC ratios}

Because carbonaceous aerosol represented a variety of emission sources, the ratio of OC to EC can be used to distinguish source characteristics. As shown in Fig. s5, the medians of OC/EC ratios at Verneuil were 11.2, 8.4, 8.3 and 9.3 from 2011 to 2014, respectively, which was comparable with those measured at forest sites in Europe (11.5 in western Germany) (Bressi et al. 2012, Kourtchev et al. 2008), about 1.5 times of those measured at rural background sites close to Paris (5.8), but much higher than those measured at European urban sites (2.6-3.1 in Barcelona, 2.8-4.7 in Amsterdam, and 3.5-4.4 in Ghent) (Kim et al. 2000, Na et al. 2004). Previous studies have shown that the $\mathrm{OC} / \mathrm{EC}$ ratio from biomass burning is very high (with a lower limit of 6.0 in Central and Southern Europe) (Gelencsér et al. 2007), whereas fossil-fuel emissions tend to have relatively low OC/EC ratios in range of 2.5-5.0 (Chen et al. 2006, Schauer et al. 2002). The OC/EC ratios with a median of $9.3(10 \%$ as 5.7 and $90 \%$ as 15.0$)$ indicated that biomass burning and/or SOA formation rather than primary traffic emission contributed strongly to the organic aerosols in Verneuil. In the absence of active biomass burning in summer/autumn, OC/EC always exhibited high values except for 2012, indicating strong SOA contribution in Verneuil, in consistent with other Europeans rural sites (Bressi et al. 2012, Khan et al. 2016, Pey et al. 2009). Taking the 
meteorological conditions into account, high average temperature and efficient solar irradiation (Table s2) resulted in strong biogenic VOC emission and active photochemical reaction (Liu et al. 2009, Peñuelas and Llusià 2003), which can partly explain significantly high OC/EC ratios in 2011 compared with 2012-2014.

3.2.3.2 Primary organic carbon (POC) and secondary organic carbon (SOC)

OC could be divided into two parts: primary organic carbon (POC) and secondary organic carbon (SOC). POC is emitted directly in the particle-phase and SOC is formed from gas-to-particle conversion in the air (Choi et al. 2012). Although the presence of SOC in aerosols can be identified by the OC/EC ratio when the ratio is higher than 2.0, it is still difficult to directly quantify the POC and SOC by chemical analysis technology (Zhang et al. 2012). The minimum OC/EC ratio method has been widely used to estimate the POC and SOC (Zhang et al. 2015), which was described as follows,

$$
\begin{aligned}
& \mathrm{POC}=\mathrm{EC}(\mathrm{OC} / \mathrm{EC})_{\min } \\
& \mathrm{SOC}=\mathrm{OC}-\mathrm{POC}
\end{aligned}
$$

The minimum OC/EC ratio in this study was 3.08, defined by the mean of the lowest $5 \%$ OC/EC values. Seasonal averages of POC and SOC mass concentration and SOC/OC ratios are given in Table 2. Annual averages of POC and SOC mass concentration were 0.69 and $1.98 \mu \mathrm{g} \cdot \mathrm{m}^{-3}, 0.67$ and $1.42 \mu \mathrm{g} \cdot \mathrm{m}^{-3}, 0.86$ and $1.67 \mu \mathrm{g} \cdot \mathrm{m}^{-3}$, 0.61 and $1.22 \mu \mathrm{g} \cdot \mathrm{m}^{-3}$ in 2011 to 2014 , respectively. Except for the winter in 2014, POC and SOC always exhibited highest in winter and lowest in summer. The latter can be explained by blowing-away effect from Atlantic Ocean air masses in summer (Hu et al. 
2014). The seeming high SOC masses in winter, however, could be overestimated using minimum-OC/EC method under biomass burning influence (Ding et al. 2012). On the other hand, increasing humidity in Verneuil in winter provided favorable meteorological conditions for SOC formation (Zhang et al. 2015). Moreover, a lower boundary layer height (BLH) in winter also favored SOC precursor stagnation and SOC formation (Duan et al. 2005).

The medians of SOC mass fractions (SOC/OC) was presented in Table 2. The significant high SOC/OC in 2011 was in consistent with OC/EC as discussed in section 3.2.3.1. The seeming seasonal tendency of SOC/OC in 2012 and 2013-high in winter/spring and low in summer/autumn, however, might be caused by the overestimation using minimum-OC/EC method under biomass burning influence of in winter/spring (Ding et al. 2012). 
Table 2 Seasonal POC and SOC concentrations and SOC/OC ratios (in median) in 2011 to 2014

\begin{tabular}{|c|c|c|c|c|c|c|c|c|c|c|c|c|}
\hline & \multicolumn{3}{|c|}{2011} & \multicolumn{3}{|c|}{2012} & \multicolumn{3}{|c|}{2013} & \multicolumn{3}{|c|}{2014} \\
\hline & $\begin{array}{l}\text { POC } \\
\mu \mathrm{g} \mathrm{m}^{-3}\end{array}$ & $\begin{array}{l}\text { SOC } \\
\mu \mathrm{g} \mathrm{m}^{-3}\end{array}$ & $\begin{array}{l}\mathrm{SOC} / \mathrm{OC} \\
\%\end{array}$ & $\begin{array}{l}\text { POC } \\
\mu \mathrm{g} \mathrm{m}^{-3}\end{array}$ & $\begin{array}{l}\text { SOC } \\
\mu \mathrm{g} \mathrm{m}^{-3}\end{array}$ & $\begin{array}{l}\mathrm{SOC} / \mathrm{OC} \\
\%\end{array}$ & $\begin{array}{l}\text { POC } \\
\mu \mathrm{g} \mathrm{m}^{-3}\end{array}$ & $\begin{array}{l}\text { SOC } \\
\mu \mathrm{g} \mathrm{m}^{-3}\end{array}$ & $\begin{array}{l}\mathrm{SOC} / \mathrm{OC} \\
\%\end{array}$ & $\begin{array}{l}\text { POC } \\
\mu \mathrm{g} \mathrm{m}^{-3}\end{array}$ & $\begin{array}{l}\text { SOC } \\
\mu \mathrm{g} \mathrm{m}^{-3}\end{array}$ & $\begin{array}{l}\mathrm{SOC} / \mathrm{OC} \\
\%\end{array}$ \\
\hline Winter & 1.19 & 3.50 & 72.7 & 0.92 & 2.58 & 71.7 & 1.07 & 1.98 & 60.6 & 0.93 & 1.18 & 57.1 \\
\hline Spring & 0.60 & 1.64 & 71.0 & 0.41 & 1.27 & 71.7 & 0.79 & 2.04 & 69.5 & 0.66 & 1.39 & 70.2 \\
\hline Summer & 0.38 & 1.28 & 73.8 & 0.37 & 0.67 & 58.7 & 0.60 & 1.36 & 58.5 & 0.48 & 1.26 & 73.2 \\
\hline Autumn & 0.80 & 2.24 & 74.2 & 0.8 & 1.14 & 53.0 & 0.74 & 1.02 & 57.1 & 0.66 & 1.22 & 62.7 \\
\hline Annual & 0.69 & 1.98 & 72.6 & 0.67 & 1.42 & 63.4 & 0.86 & 1.67 & 63.1 & 0.61 & 1.22 & 67.0 \\
\hline
\end{tabular}




\subsubsection{Levoglucosan and $\mathrm{K}^{+}$}

Levoglucosan and $\mathrm{K}^{+}$have been considered as tracer for biomass burning (BB). Recent reports pointed out that using levoglucosan as BB tracer was less interfered since there can be other sources for $\mathrm{K}^{+}$in addition to BB (Caseiro et al. 2009). However, due to the absence of levoglucosan measurement in 2011 and 2012, consistency between $\mathrm{K}^{+}$and levoglucosan was analyzed. Mass concentrations of $\mathrm{K}^{+}$and levoglucosan are given in Fig. 2 (e), which were strongly correlated with a $\mathrm{R}^{2}=0.79$ (Fig. s6). This correlation coefficient was in consistency with previous study $\left(\mathrm{R}^{2}=0.81\right)$ for typical biomass burning (Urban et al. 2012). However, it should be noticed that Levoglucosan occasionally appeared low $\left(<100 \mathrm{ng} \mathrm{m}^{-3}\right)$ even if $\mathrm{K}^{+}$exceeded $50 \mathrm{ng} \mathrm{m}^{-3}$ (background concentration), implying $\mathrm{K}^{+}$might originate from other sources such as agricultural activities rather than biomass burning. On the other hand, Levoglucosan always appeared high $\left(>300 \mathrm{ng} \mathrm{m}^{-3}\right)$ when $\mathrm{K}^{+}$exceeded $100 \mathrm{ng} \mathrm{m}^{-3}$, reliable for identifying biomass burning events. The surroundings in Verneuil was mainly vegetations and didn't change in 2011-2014; possible $\mathrm{K}^{+}$sources such as soil resuspension, fertilizers, seawater and waste incinerator were limited. Took them into account and compared with studies from other five European countries (Jedynska et al. 2014, Reche et al. 2012), $\mathrm{K}^{+}$could be regarded as a reliable biomass burning tracer at Verneuil when higher than $100 \mathrm{ng} \mathrm{m}^{-3}$ for 2011 and 2012 in the absence of Levoglucosan measurement. Taking event 1 as an example, the high $\mathrm{K}^{+}$concentration of $556 \mathrm{ng} \cdot \mathrm{m}^{-3}$ on Jan 31, 2011 indicated that this pollution event was significantly 
influenced by biomass burning, in consistence with a high OC/EC ratio of 15.4. Further discussion on biomass burning tracers in section 3.2.4 implied that biomass burning had remarkable impact on $\mathrm{PM}_{2.5}$ in Verneuil.

\subsection{Cluster analysis}

Backward trajectory cluster analysis was utilized to identify the $\mathrm{PM}_{2.5}$ sources that influenced Verneuil site. 48-hour back trajectories at $100 \mathrm{~m}$ a.g.l. (meter above ground level) altitude with time resolution of 3 hours were clustered into 4 main trajectories for seasons from 2011 to 2014 as showed in Fig. 6.

As illustrated in Fig. 6, air masses arriving at Verneuil came from north to northeast, west and south directions. Fastest air flows came from west were always with lower $\mathrm{PM}_{2.5}$ concentrations which indicated that the Atlantic flows brought clean air to the center France. Southerly air flows came from mountainous areas and the west Mediterranean Sea, which had PM2.5 concentrations higher than those of westerly flows but lower than those of northerly flows. Northeasterly air flows crossed central European regions such as Belgium, Netherland and west Germany, which accounted for $20 \%$ to $30 \%$ in different seasons. And average $\mathrm{PM}_{2.5}$ concentrations of air masses came from these regions were $23.8,23.1,10.4$ and $12.0 \mu \mathrm{g} \mathrm{m}^{-3}$ for winter, spring, summer and autumn, which were the highest ones among those of westerly and southerly flows in the same season. Thus, it was suggested that the pollutants caused by atmospheric transport were mainly came from regions and countries located in northeast of Verneuil. 


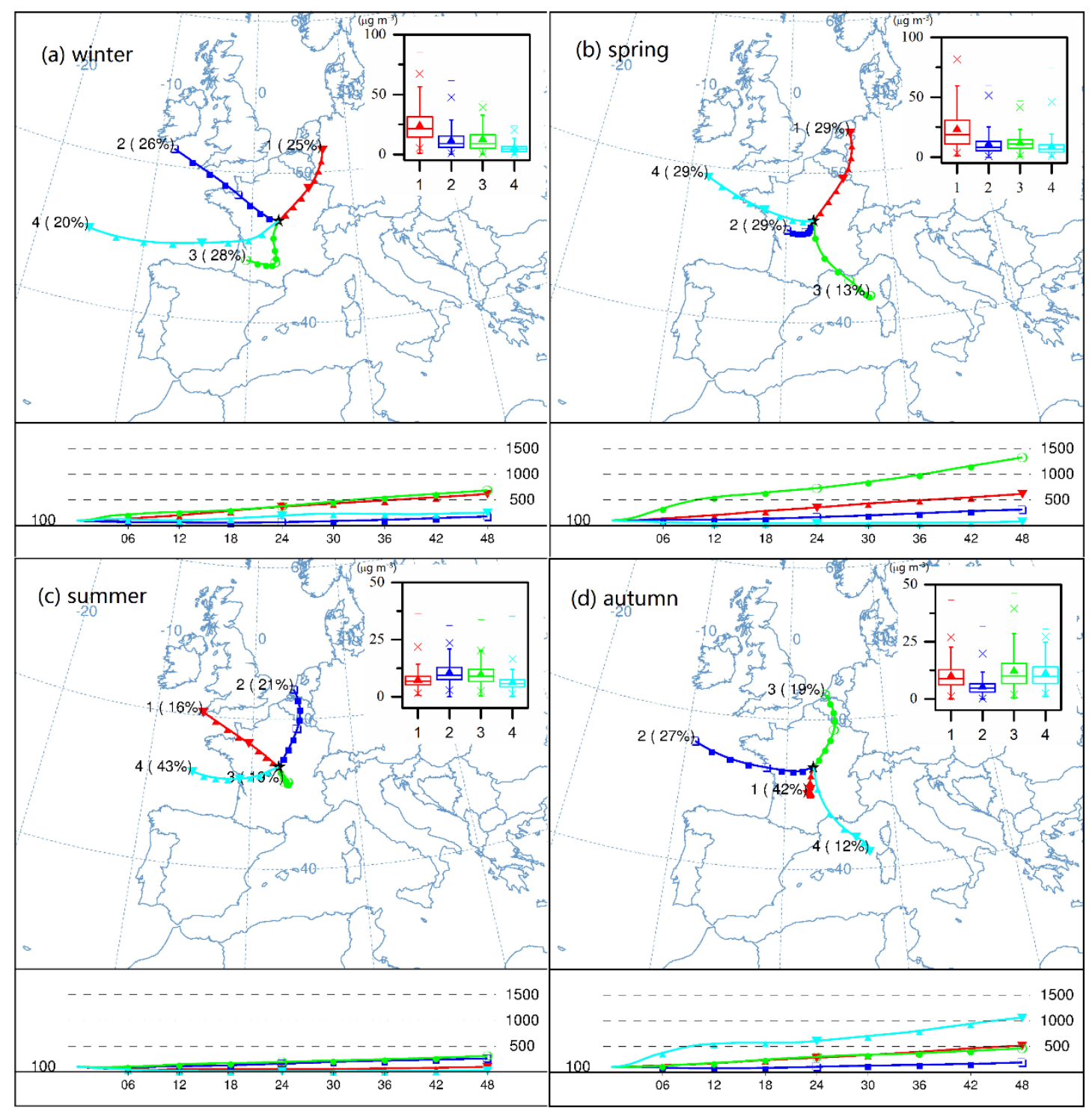

Fig. 6 Seasonal 48-hours backward trajectory clusters at $100 \mathrm{~m}$ a.g.l. (above ground level) altitude with corresponding statistic $\mathrm{PM}_{2.5}$ mass concentrations (small interior figures) from 2011 to 2014. A solid triangle denotes the average. The horizontal line across the box is the median, the lower and upper hinges represent the $25^{\text {th }}$ and $75^{\text {th }}$ percentiles, respectively, while the lower and upper cross represent the $1^{\text {st }}$ and $99^{\text {th }}$ percentiles, respectively. The bottom and top line represent the minimum and maximum, respectively. 
Table 3 Pollution event list

\begin{tabular}{|c|c|c|c|c|c|}
\hline Event & Period & $\begin{array}{l}\text { Highest } \mathrm{PM}_{2.5} \text { mass } \\
\text { concentration }\left(\mu \mathrm{g} \mathrm{m}^{-3}\right)\end{array}$ & $\operatorname{SIA}\left(\mu \mathrm{g} \mathrm{m}^{-3}\right)^{\mathrm{b}}$ & $\mathrm{OC} / \mathrm{EC}^{\mathrm{b}}$ & $\begin{array}{l}\text { Levoglucosan } / \mathrm{K}^{+} \\
\left(\mathrm{ng} \mathrm{m}^{-3}\right)^{\mathrm{a}, \mathrm{b}}\end{array}$ \\
\hline 1 & $29 / 01 / 2011-02 / 02 / 2011$ & $55.7(31 / 01 / 2011)$ & 33.0 & 15.4 & NA/556.2 \\
\hline 2 & 01/03/2011 - 07/03/2011 & $78.8(05 / 03 / 2011)$ & 25.6 & 10.2 & NA/151.6 \\
\hline 3 & 01/02/2012 - 13/02/2012 & $53.3(13 / 02 / 2012)$ & 20.3 & 12.5 & $\mathrm{NA} / 257.8$ \\
\hline 4 & $25 / 03 / 2013-07 / 04 / 2013$ & $63.8(31 / 03 / 2013)$ & 30.6 & 13.3 & $583.7 / 165.4$ \\
\hline 5 & $11 / 03 / 2014-15 / 03 / 2014$ & $62.0(15 / 03 / 2014)$ & 25.4 & 8.5 & $234.0 / 181.2$ \\
\hline
\end{tabular}

${ }^{\mathrm{a}}$ NA means data Not Available

${ }^{\mathrm{b}}$ Values were the averages during corresponding event 


\subsection{Identification of pollution events}

As listed in Table 3, five heavy pollution events occurred during the four years. The period of event was defined from the first day when $\mathrm{PM}_{2.5}$ mass concentration became higher than $25 \mu \mathrm{g} \cdot \mathrm{m}^{-3}$ in continuous 3 days, and until the first day when it became lower than $25 \mu \mathrm{g} \cdot \mathrm{m}^{-3}$ in continuous 3 days.

Fig. s7 illustrated the 5-days backward trajectories as well as fire spots distribution during the pollution periods and clean days. Evidently, these events had strong relationship with air mass transport. Before and after the pollution periods, air masses mainly originated from the Atlantic with low $\mathrm{PM}_{2.5}$ levels. As illustrated in Fig. s9, sea salt contributed more during these clean days. While during the heavy pollution periods, air masses mainly came from central European countries.

It should be noted that backward trajectories of Event 5 traced to area with intensive wild fire spots in East Europe regions. This event was recorded by the sample collected on March 13 ${ }^{\text {th }}, 2014$. 5-days backward trajectory clusters, fire spots and mass concentrations for $\mathrm{PM}_{2.5}$ and its main components are illustrated in Fig. 7. The high levoglucosan mass concentration $\left(424.5 \mathrm{ng} \cdot \mathrm{m}^{-3}\right)$ and OC/EC ratio (8.5) could be indicators of the impact of biomass burning (Cao et al. 2009). And high SIA contribution was related to long-range atmospheric transport. To summarize, event 5 was mainly caused by long-rang transport biomass burning plumes originated from East Europe. 


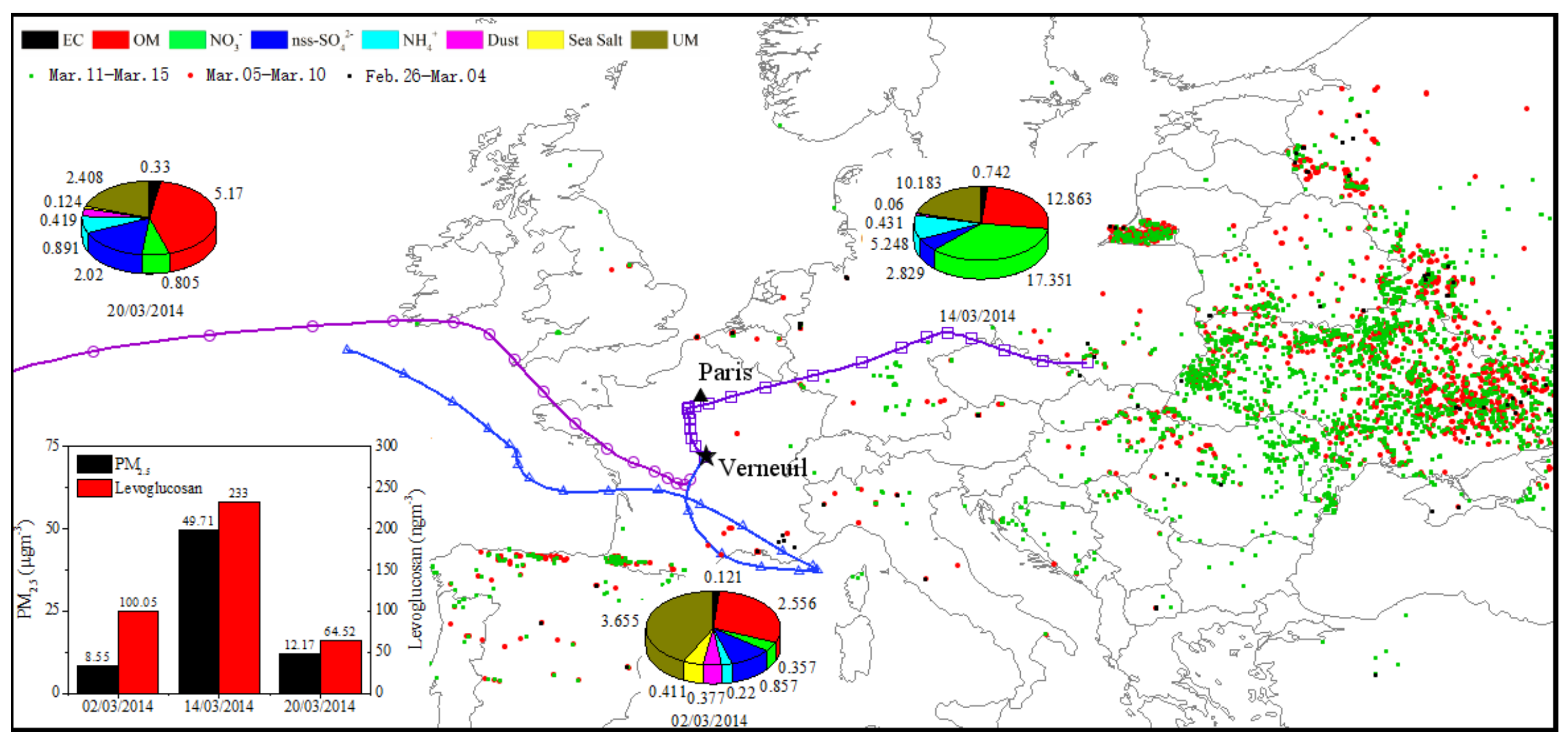

Fig. 7 5-days backward trajectory clusters at $100 \mathrm{~m}$ a.g.l. altitude with corresponding wild fire spots distribution and mass concentrations of $\mathrm{PM}_{2.5}$, levoglucosan and main components during the period of Event 5. Single trajectories were calculated per hour. Units of main components were in $\mu \mathrm{g} \mathrm{m}^{-3}$. 
Mass concentrations of main composition in $\mathrm{PM}_{2.5}$ for pollution days during events 1 to 4 and clean days after or before these events are given in Fig. s9. High concentrations of biomass burning tracers $\left(\mathrm{K}^{+} / \operatorname{levoglucosan}\right)$ were found during the periods of events 1 to 4 , but fire spots were not evidently observed here. These events were influenced by biomass burning but slightly from fire spots we got. Compared to other events in the spring, event 1 and 3 happened in January and early February with the highest $\mathrm{K}^{+}$concentrations (556 and $215 \mathrm{ng} \cdot \mathrm{m}^{-3}$ ) and $\mathrm{OM}$ contributions (26.8 and 15.0\%), which means more biomass burnings in winter. And according to other researches in France, they were mainly from domestic heating (Kfoury et al. 2016). SIA, which increased from $11.19,7.02,3.84$ and $0.79 \mu \mathrm{g} \cdot \mathrm{m}^{-3}$ during clean days to 32.98 , $25.57,24.57$ and $33.88 \mu \mathrm{g} \cdot \mathrm{m}^{-3}$ during pollution days, accounted for the most part of $\mathrm{PM}_{2.5}$ in these events, especially for Event 2 and 4 which appeared in spring. As a rural measurement site, without local emission sources, pollutants were mainly imported from regions and countries located east of Verneuil. Meantime, these countries in central Europe used more fossil fuels for the energy production and more woods for residence heating during cold days, which would contribute a lot to $\mathrm{PM}_{2.5}$ and lead to high levels of $\mathrm{K}^{+}$and levoglucosan, as well as high levels of SIA precursors, $\mathrm{NO}_{\mathrm{x}}$ and $\mathrm{SO}_{2}$ (Rogula-Kozłowska et al. 2014). And with mid- or long-range atmospheric transport and complex reactions, these SIA precursors leaded to a high level of SIA.

Meteorological data in Fig. s8 also showed that these events occurred in the coldest and temperature dropping days when there would be more fossil fuel and wood burnings. Thus, it was suggested that Events 1 to 4 were mainly impacted by aerosols 
from fossil fuel combustion and biomass burning in central European countries during cold days, and these aerosols were brought to Verneuil site by the mid- or long-range transport. Additionally, BLH was usually low in winter, which may lead to pollutant accumulations (Salmond 2005).

\section{Conclusions}

In this study, $\mathrm{PM}_{2.5}$ and its main chemical species were investigated at a rural background site in central France (Val-de-Loire region) from 2011 to 2014. PM2.5 contributed predominately to particle pollution in Verneuil site as indicated by high $\mathrm{PM}_{2.5} / \mathrm{PM}_{10}$ ratios. Annual average mass concentrations of $\mathrm{PM}_{2.5}$ were 1.8, 9.5, 12.6 and $10.2 \mu \mathrm{g} \cdot \mathrm{m}^{-3}$ in 2011 to 2014 , respectively. $\mathrm{PM}_{2.5}$ concentrations showed similar seasonal pattern from 2011 to 2014 with high levels in spring and winter and low levels in summer and autumn. OM and SIA, which accounted for 30.1\% 41.8\% and 36.9\% $\sim 46.3 \%$, respectively, were major components in $\mathrm{PM}_{2.5}$. OM contributed more in the winter while SIA $\left(\mathrm{NO}_{3}{ }^{-}, \mathrm{nss}_{-} \mathrm{SO}_{4}{ }^{2-}\right.$ and $\left.\mathrm{NH}_{4}{ }^{+}\right)$shares showed clear seasonal tendency in the order of spring $>$ winter $>$ autumn $>$ summer. High OM shares in Verneuil was largely attributed to biomass burning and/or SOA formation in winter/spring, while solely to SOA formation in summer/autumn. SIA, characterized to be ammoniumsaturated, originated from transport from Europe inland and gas-to-particle conversion by precursors $\left(\mathrm{SO}_{2} \mathrm{NO}_{x}, \mathrm{NH}_{3}\right)$ in excess of ammonia under favorable thermodynamic conditions. OC/EC ratios indicated that the influence of biomass burning and SOC contributed strongly to the organic aerosols in Verneuil site. Meteorological conditions 
appeared Mass concentrations of levoglucosan and $\mathrm{K}^{+}$also proved the impact of biomass burning on the particle pollution in Verneuil. Backward trajectory cluster analysis implied the air masses with high $\mathrm{PM}_{2.5}$ levels had strong relationship with atmospheric transport from central Europe. Finally, five heavy pollution events were identified and results showed not only the polluted air masses from Central Europe but also the biomass burning from East Europe will influence the air quality in Verneuil.

\section{Acknowledgement}

This work was supported by the European Community's Seventh Framework Programme Marie Curie Actions IRSES under the grant agreement $n^{\circ} 069720$ (AMIS), the Labex Voltaire (ANR-10-LABX-100-01) and ARD/ CPER (2015 -2020) PIVOTS program (supported by the Centre-Val de Loire regional council).

\section{References}

Amodio, M., Andriani, E., Cafagna, I., Caselli, M., Daresta, B.E., de Gennaro, G., Di Gilio, A., Placentino, C.M. and Tutino, M. (2010) A statistical investigation about sources of PM in South Italy. Atmospheric Research 98(2-4), 207-218, http://dx.doi.org/10.1016/j.atmosres.2010.03.023

Barker, T., Bashmakov, I., Bernstein, L., Bogner, J.E., Bosch, P.R., Dave, R., Metz, B. and Nabuurs, G.J. (2007) Contribution of Working Group I to the Fourth Assessment Report of the IPCC. 
Beekmann, M., Prévôt, A.S.H., Drewnick, F., Sciare, J., Pandis, S.N., Denier van der Gon, H.A.C., Crippa, M., Freutel, F., Poulain, L., Ghersi, V., Rodriguez, E., Beirle, S., Zotter, P., von der Weiden-Reinmüller, S.L., Bressi, M., Fountoukis, C., Petetin, H., Szidat, S., Schneider, J., Rosso, A., El Haddad, I., Megaritis, A., Zhang, Q.J., Michoud, V., Slowik, J.G., Moukhtar, S., Kolmonen, P., Stohl, A., Eckhardt, S., Borbon, A., Gros, V., Marchand, N., Jaffrezo, J.L., Schwarzenboeck, A., Colomb, A., Wiedensohler, A., Borrmann, S., Lawrence, M., Baklanov, A. and Baltensperger, U. (2015) In situ, satellite measurement and model evidence on the dominant regional contribution to fine particulate matter levels in the Paris megacity. Atmos. Chem. Phys. 15(16), 9577-9591, http://dx.doi.org/10.5194/acp-

\section{$\underline{15-9577-2015}$}

Birch, M.E. (1998) Analysis of carbonaceous aerosols: Interlaboratory comparison. Analyst 123(5), 851-857, http://dx.doi.org/10.1039/a800028j

Bressi, M., Sciare, J., Ghersi, V. and Bonnaire, N. (2012) A one-year comprehensive chemical characterisation of fine aerosol (PM2.5) at urban, suburban and rural background sites in the region of Paris (France). Atmospheric Chemistry and Physics Discussions, http://dx.doi.org/10.5194/acpd-12-29391-2012

Cao, J.-J., Xu, B.-Q., He, J.-Q., Liu, X.-Q., Han, Y.-M., Wang, G.-h. and Zhu, C.-s. (2009) Concentrations, seasonal variations, and transport of carbonaceous aerosols at a remote Mountainous region in western China. Atmospheric Environment 43(29), 4444-4452, http://dx.doi.org/10.1016/j.atmosenv.2009.06.023

Caseiro, A., Bauer, H., Schmidl, C., Pio, C.A. and Puxbaum, H. (2009) Wood burning 
impact on PM10 in three Austrian regions. Atmospheric Environment 43(13), 2186-2195, http://dx.doi.org/10.1016/j.atmosenv.2009.01.012

Cavalli, F., Viana, M., Yttri, K.E., Genberg, J. and Putaud, J.P. (2010) Toward a standardised thermal-optical protocol for measuring atmospheric organic and elemental carbon: the EUSAAR protocol. Atmos. Meas. Tech. 3(1), 79-89, 10.5194/amt-3-79-2010

Cazier, F., Genevray, P., Dewaele, D., Nouali, H., Verdin, A., Ledoux, F., Hachimi, A., Courcot, L., Billet, S., Bouhsina, S., Shirali, P., Garçon, G. and Courcot, D. (2016) Characterisation and seasonal variations of particles in the atmosphere of rural, urban and industrial areas: Organic compounds. Journal of Environmental Sciences 44, 45-56, http://dx.doi.org/10.1016/j.jes.2016.01.014

Chen, Y., Zhi, G., Feng, Y., Fu, J., Feng, J., Sheng, G. and Simoneit, B.R. (2006) Measurements of emission factors for primary carbonaceous particles from residential raw-coal combustion in China. Geophysical Research Letters 33(20), http://dx.doi.org/10.1029/2006GL026966

Choi, J.-K., Heo, J.-B., Ban, S.-J., Yi, S.-M. and Zoh, K.-D. (2012) Chemical characteristics of PM2.5 aerosol in Incheon, Korea. Atmospheric Environment 60, 583-592, http://dx.doi.org/10.1016/j.atmosenv.2012.06.078

Chow, J.C., Fujita, E.M., Watson, J.G., Lu, Z., Lawson, D.R. and Ashbaugh, L.L. (1994) Evaluation of filter-based aerosol measurements during the 1987 Southern California Air Quality Study. Environ Monit Assess 30(1), 49-80, 10.1007/BF00546199 
Chow, J.C., Watson, J.G., Pritchett, L.C., Pierson, W.R., Frazier, C.A. and Purcell, R.G. (1993) The dri thermal/optical reflectance carbon analysis system: description, evaluation and applications in U.S. Air quality studies. Atmospheric Environment. Part A. General Topics 27(8), 1185-1201, http://dx.doi.org/10.1016/0960$\underline{1686(93) 90245-\mathrm{T}}$

Clegg, S.L., Brimblecombe, P. and Wexler, A.S. (1998) Thermodynamic Model of the System $\mathrm{H}+-\mathrm{NH} 4+-\mathrm{SO} 42--\mathrm{NO} 3--\mathrm{H} 2 \mathrm{O}$ at Tropospheric Temperatures. The Journal of Physical Chemistry A 102(12), 2137-2154, 10.1021/jp973042r

Dimitriou, K. and Kassomenos, P. Combining AOT, Angstrom Exponent and PM concentration data, with PSCF model, to distinguish fine and coarse aerosol intrusions in Southern France. Atmospheric Research 172-173, 74-82, http://dx.doi.org/10.1016/j.atmosres.2016.01.002

Ding, X., Wang, X.M., Gao, B., Fu, X.X., He, Q.F., Zhao, X.Y., Yu, J.Z. and Zheng, M. (2012) Tracer-based estimation of secondary organic carbon in the Pearl River Delta, south China. Journal of Geophysical Research Atmospheres 117(D5), 5313,

Duan, F., He, K., Ma, Y., Jia, Y., Yang, F., Lei, Y., Tanaka, S. and Okuta, T. (2005) Characteristics of carbonaceous aerosols in Beijing, China. Chemosphere 60(3), 355-364, http://dx.doi.org/10.1016/j.chemosphere.2004.12.035

El Haddad, I., Marchand, N., Wortham, H., Piot, C., Besombes, J.L., Cozic, J., Chauvel, C., Armengaud, A., Robin, D. and Jaffrezo, J.L. (2011) Primary sources of $\mathrm{PM}<\mathrm{sub}>2.5</ \mathrm{sub}>$ organic aerosol in an industrial Mediterranean city, Marseille. Atmos. Chem. Phys. 11(5), 2039-2058, http://dx.doi.org/10.5194/acp-11-2039- 
Fortems-Cheiney, A., Dufour, G., Hamaoui-Laguel, L., Foret, G., Siour, G., Van Damme, M., Meleux, F., Coheur, P.F., Clerbaux, C., Clarisse, L., Favez, O., Wallasch, M. and Beekmann, M. (2016) Unaccounted variability in NH3 agricultural sources detected by IASI contributing to European spring haze episode. Geophysical Research Letters 43(10), 2016GL069361, http://dx.doi.org/10.1002/2016GL069361

Gelencsér, A., May, B., Simpson, D., Sánchez-Ochoa, A., Kasper-Giebl, A., Puxbaum, H., Caseiro, A., Pio, C. and Legrand, M. (2007) Source apportionment of PM2. 5 organic aerosol over Europe: Primary/secondary, natural/anthropogenic, and fossil/biogenic origin. Journal of Geophysical Research: Atmospheres 112(D23), http://dx.doi.org/10.1029/2006JD008094

Guieu, C., Loÿe-Pilot, M.D., Ridame, C. and Thomas, C. (2002) Chemical characterization of the Saharan dust end-member: Some biogeochemical implications for the western Mediterranean Sea. Journal of Geophysical Research Atmospheres 107(D15), ACH 5-1-ACH 5-11,

Guinot, B., Cachier, H. and Oikonomou, K. (2007) Geochemical perspectives from a new aerosol chemical mass closure. Atmos. Chem. Phys. 7(6), 1657-1670, $10.5194 /$ acp-7-1657-2007

Hamaoui, L. (2012) Les émissions d'ammoniac par les activités agricoles: impact sur la qualité de l'air, Paris 7.

Hu, D., Li, L., Idir, M., Mellouki, A. and Chen, J. (2014) Size Distribution and Optical 
Properties of Ambient Aerosols during Autumn in Orleans, France. Aerosol \& Air Quality Research 14(3), 744-755, http://dx.doi.org/10.4209/aaqr.2013.07.0252

Huang, X., Qiu, R., Chan, C.K. and Ravi Kant, P. (2011) Evidence of high PM2.5 strong acidity in ammonia-rich atmosphere of Guangzhou, China: Transition in pathways of ambient ammonia to form aerosol ammonium at $[\mathrm{NH} 4+] /[\mathrm{SO} 42-]=1.5$. $\begin{array}{lll}\text { Atmospheric } & \text { Research } & \text { 99(3-4), }\end{array}$ http://dx.doi.org/10.1016/j.atmosres.2010.11.021

Jean-P., P., Frank, R., Rita, V.D., Erika, B., M.-Cristina, F., Stefano, D., Sandro, F., Robert, G., Cristoph, H. and Paolo, L. (2003) A European aerosol phenomenology2: chemical characteristics of particulate matter at kerbside, urban, rural and background sites in Europe. Atmos Environ, European Commission.

Jedynska, A., Hoek, G., Wang, M., Eeftens, M., Cyrys, J., Beelen, R., Cirach, M., De Nazelle, A., Nystad, W., Makarem Akhlaghi, H., Meliefste, K., Nieuwenhuijsen, M., de Hoogh, K., Brunekreef, B. and Kooter, I.M. (2014) Spatial variations and development of land use regression models of levoglucosan in four European study areas. Atmos. Chem. Phys. Discuss. 2014, 13491-13527, 10.5194/acpd-14$13491-2014$

Kfoury, A., Ledoux, F., Roche, C., Delmaire, G., Roussel, G. and Courcot, D. (2016) PM2.5 source apportionment in a French urban coastal site under steelworks emission influences using constrained non-negative matrix factorization receptor model. Journal of Environmental Sciences 40, 114-128, http://dx.doi.org/10.1016/j.jes.2015.10.025 
Khan, M.B., Masiol, M., Formenton, G., Di Gilio, A., de Gennaro, G., Agostinelli, C. and Pavoni, B. (2016) Carbonaceous PM2.5 and secondary organic aerosol across the Veneto region (NE Italy). Science of The Total Environment 542, Part A, 172181, http://dx.doi.org/10.1016/j.scitotenv.2015.10.103

Kim, B.M., Teffera, S. and Zeldin, M.D. (2000) Characterization of PM25 and PM10 in the South Coast Air Basin of Southern California: Part 1-Spatial Variations. Journal of the Air \& Waste Management Association 50(12), 2034-2044, http://dx.doi.org/10.1080/10473289.2000.10464242

Koçak, M., Mihalopoulos, N. and Kubilay, N. (2007) Contributions of natural sources to high and events in the eastern Mediterranean. Atmospheric Environment 41(18), 3806-3818, http://dx.doi.org/10.1016/j.atmosenv.2007.01.009

Kourtchev, I., Warnke, J., Maenhaut, W., Hoffmann, T. and Claeys, M. (2008) Polar organic marker compounds in PM2.5 aerosol from a mixed forest site in western Germany. Chemosphere 73(8), 1308-1314, http://dx.doi.org/10.1016/j.chemosphere.2008.07.011

Li, Y., Cao, J., Li, J., Zhou, J., Xu, H., Zhang, R. and Ouyang, Z. (2013) Molecular distribution and seasonal variation of hydrocarbons in PM2.5 from Beijing during 2006. Particuology 11(1), 78-85, http://dx.doi.org/10.1016/j.partic.2012.09.002

Liu, X., Zhang, W., Huang, M., Wang, Z., Hao, L. and Zhao, W. (2009) Effect of illumination intensity and light application time on secondary organic aerosol formation from the photooxidation of $\alpha$-pinene. Journal of Environmental Sciences 21(4), 447-451, http://dx.doi.org/10.1016/S1001-0742(08)62290-1 
Maté, T., Guaita, R., Pichiule, M., Linares, C. and Díaz, J. (2010) Short-term effect of fine particulate matter (PM2.5) on daily mortality due to diseases of the circulatory system in Madrid (Spain). Science of The Total Environment 408(23), 5750-5757, http://dx.doi.org/10.1016/j.scitotenv.2010.07.083

Na, K., Sawant, A.A., Song, C. and Cocker Iii, D.R. (2004) Primary and secondary carbonaceous species in the atmosphere of Western Riverside County, California. Atmospheric $\quad$ Environment $\quad 38(9), \quad 1345-1355$, http://dx.doi.org/10.1016/j.atmosenv.2003.11.023

OECD. (2014) OECD Factbook 2014: Renewable energy, OECD Publishing.

Patashnick, H. and Rupprecht, E.G. (1991) Continuous PM-10 Measurements Using the Tapered Element Oscillating Microbalance. Journal of the Air \& Waste Management Association 1079-1083, http://dx.doi.org/10.1080/10473289.1991.10466903

Pateraki, S., Asimakopoulos, D.N., Bougiatioti, A., Maggos, T., Vasilakos, C. and Mihalopoulos, N. (2014) Assessment of PM2.5 and PM1 chemical profile in a multiple-impacted Mediterranean urban area: Origin, sources and meteorological dependence. Science of The Total Environment 479-480, 210-220, http://dx.doi.org/10.1016/j.scitotenv.2014.02.008

Pathak, R.K., Wang, T., Ho, K.F. and Lee, S.C. (2011) Characteristics of summertime PM2.5 organic and elemental carbon in four major Chinese cities: Implications of high acidity for water-soluble organic carbon (WSOC). Atmospheric Environment 45(2), 318-325, http://dx.doi.org/10.1016/j.atmosenv.2010.10.021 
Pathak, R.K., Wu, W.S. and Wang, T. (2009) Summertime PM2.5 ionic species in four major cities of China: nitrate formation in an ammonia-deficient atmosphere. Atmos. Chem. Phys. 9(5), 1711-1722, http://dx.doi.org/10.5194/acp-9-1711-2009

Peñuelas, J. and Llusià, J. (2003) BVOCs: plant defense against climate warming? Trends in Plant Science 8(3), 105-109, http://dx.doi.org/10.1016/S1360-

\section{$\underline{1385(03) 00008-6}$}

Pey, J., Pérez, N., Castillo, S., Viana, M., Moreno, T., Pandolfi, M., López-Sebastián, J.M., Alastuey, A. and Querol, X. (2009) Geochemistry of regional background aerosols in the Western Mediterranean. Atmospheric Research 94(3), 422-435, http://dx.doi.org/10.1016/j.atmosres.2009.07.001

Pirovano, G., Colombi, C., Balzarini, A., Riva, G.M., Gianelle, V. and Lonati, G. (2015) PM2.5 source apportionment in Lombardy (Italy): Comparison of receptor and chemistry-transport modelling results. Atmospheric Environment 106, 56-70, http://dx.doi.org/10.1016/j.atmosenv.2015.01.073

Putaud, J.P., Van Dingenen, R., Alastuey, A., Bauer, H., Birmili, W., Cyrys, J., Flentje, H., Fuzzi, S., Gehrig, R., Hansson, H.C., Harrison, R.M., Herrmann, H., Hitzenberger, R., Hüglin, C., Jones, A.M., Kasper-Giebl, A., Kiss, G., Kousa, A., Kuhlbusch, T.A.J., Löschau, G., Maenhaut, W., Molnar, A., Moreno, T., Pekkanen, J., Perrino, C., Pitz, M., Puxbaum, H., Querol, X., Rodriguez, S., Salma, I., Schwarz, J., Smolik, J., Schneider, J., Spindler, G., ten Brink, H., Tursic, J., Viana, M., Wiedensohler, A. and Raes, F. (2010) A European aerosol phenomenology 3: Physical and chemical characteristics of particulate matter from 60 rural, urban, 
and kerbside sites across Europe. Atmospheric Environment 44(10), 1308-1320, http://dx.doi.org/10.1016/j.atmosenv.2009.12.011

Razak, I.S., Latif, M.T., Jaafar, S.A., Khan, M.F. and Mushrifah, I. (2015) Surfactants in atmospheric aerosols and rainwater around lake ecosystem. Environmental Science and Pollution Research 22(8), 6024-6033, http://dx.doi.org/10.1007/s11356-014-3781-z

Reche, C., Viana, M., Amato, F., Alastuey, A., Moreno, T., Hillamo, R., Teinilä, K., Saarnio, K., Seco, R., Peñuelas, J., Mohr, C., Prévôt, A.S.H. and Querol, X. (2012) Biomass burning contributions to urban aerosols in a coastal Mediterranean City. Science of The Total Environment 427, 175-190, http://dx.doi.org/10.1016/j.scitotenv.2012.04.012

Rogula-Kozłowska, W., Klejnowski, K., Rogula-Kopiec, P., Ośródka, L., Krajny, E., Błaszczak, B. and Mathews, B. (2014) Spatial and seasonal variability of the mass concentration and chemical composition of PM2.5 in Poland. Air Quality, Atmosphere \& Health 7(1), 41-58, http://dx.doi.org/10.1007/s11869-013-0222-y

Salmond, J.A. (2005) A review of turbulence in the very stable nocturnal boundary layer and its implications for air quality. Progress in Physical Geography 29(2), 171-188,

Samara, C., Voutsa, D., Kouras, A., Eleftheriadis, K., Maggos, T., Saraga, D. and Petrakakis, M. (2013) Organic and elemental carbon associated to PM10 and PM2.5 at urban sites of northern Greece. Environmental Science and Pollution Research 21(3), 1769-1785, http://dx.doi.org/10.1007/s11356-013-2052-8 
Schauer, J.J., Kleeman, M.J., Cass, G.R. and Simoneit, B.R. (2002) Measurement of emissions from air pollution sources. 5. C1-C32 organic compounds from gasoline-powered motor vehicles. Environmental Science \& Technology 36(6), 1169-1180,

Sciare, J., Oikonomou, K., Cachier, H. and Mihalopoulos, N. (2005) Aerosol mass closure and reconstruction of the light scattering coefficient over the Eastern Mediterranean Sea during the MINOS campaign. Atmospheric Chemistry and Physics Discussions, http://dx.doi.org/

Seinfeld, J.H., Pandis, S.N., Seinfeld, J.H. and Pandis, S.N. (2006) Atmospheric chemistry and physics: from air pollution to climate change. Physics Today 51(2), 212-214(213), http://dx.doi.org/10.1023/A:1006483708571

Sisler, J.F. and Huffman, D. (1994) Spatial and seasonal trends in particle concentration and optical extinction in the United States. J Geophys Res. Journal of Geophysical Research Atmospheres 99(D1), 1347-1370,

Srinivas, B. and Sarin, M.M. (2014) PM2.5, EC and OC in atmospheric outflow from the Indo-Gangetic Plain: Temporal variability and aerosol organic carbon-toorganic mass conversion factor. Science of The Total Environment 487, 196-205, http://dx.doi.org/10.1016/j.scitotenv.2014.04.002

Stein, A.F., Draxler, R.R., Rolph, G.D., Stunder, B.J.B., Cohen, M.D. and Ngan, F. (2015) NOAA's HYSPLIT Atmospheric Transport and Dispersion Modeling System. Bulletin of the American Meteorological Society 96(12),

Tao, J., Shen, Z., Zhu, C., Yue, J., Cao, J., Liu, S., Zhu, L. and Zhang, R. (2012) 
Seasonal variations and chemical characteristics of sub-micrometer particles (PM1) in Guangzhou, China. Atmospheric Research 118, 222-231, http://dx.doi.org/10.1016/j.atmosres.2012.06.025

Tian, Y.-Z., Shi, G.-L., Huang-Fu, Y.-Q., Song, D.-L., Liu, J.-Y., Zhou, L.-D. and Feng, Y.-C. (2016) Seasonal and regional variations of source contributions for PM10 and PM2.5 in urban environment. Science of The Total Environment 557-558, 697-704, http://dx.doi.org/10.1016/j.scitotenv.2016.03.107

Turpin, B.J. and Lim, H.-J. (2001) Species Contributions to PM2.5 Mass Concentrations: Revisiting Common Assumptions for Estimating Organic Mass. Aerosol Science and Technology 35(1), 602-610, http://dx.doi.org/10.1080/02786820119445

Urban, R.C., Lima-Souza, M., Caetano-Silva, L., Queiroz, M.E.C., Nogueira, R.F.P., Allen, A.G., Cardoso, A.A., Held, G. and Campos, M.L.A.M. (2012) Use of levoglucosan, potassium, and water-soluble organic carbon to characterize the origins of biomass-burning aerosols. Atmospheric Environment 61, 562-569, http://dx.doi.org/10.1016/j.atmosenv.2012.07.082

WHO, W.H.O. (2006) Air quality guidelines: global update 2005: particulate matter, ozone, nitrogen dioxide, and sulfur dioxide, World Health Organization.

Zhang, F., Wang, Z.-w., Cheng, H.-r., Lv, X.-p., Gong, W., Wang, X.-m. and Zhang, G. (2015) Seasonal variations and chemical characteristics of PM2.5 in Wuhan, central China. Science of The Total Environment 518-519, 97-105, http://dx.doi.org/10.1016/j.scitotenv.2015.02.054 
Zhang, F., Xu, L., Chen, J., Yu, Y., Niu, Z. and Yin, L. (2012) Chemical compositions and extinction coefficients of PM2.5 in peri-urban of Xiamen, China, during June 2009-May 2010. Atmospheric Research 106, 150-158, http://dx.doi.org/10.1016/j.atmosres.2011.12.005 